
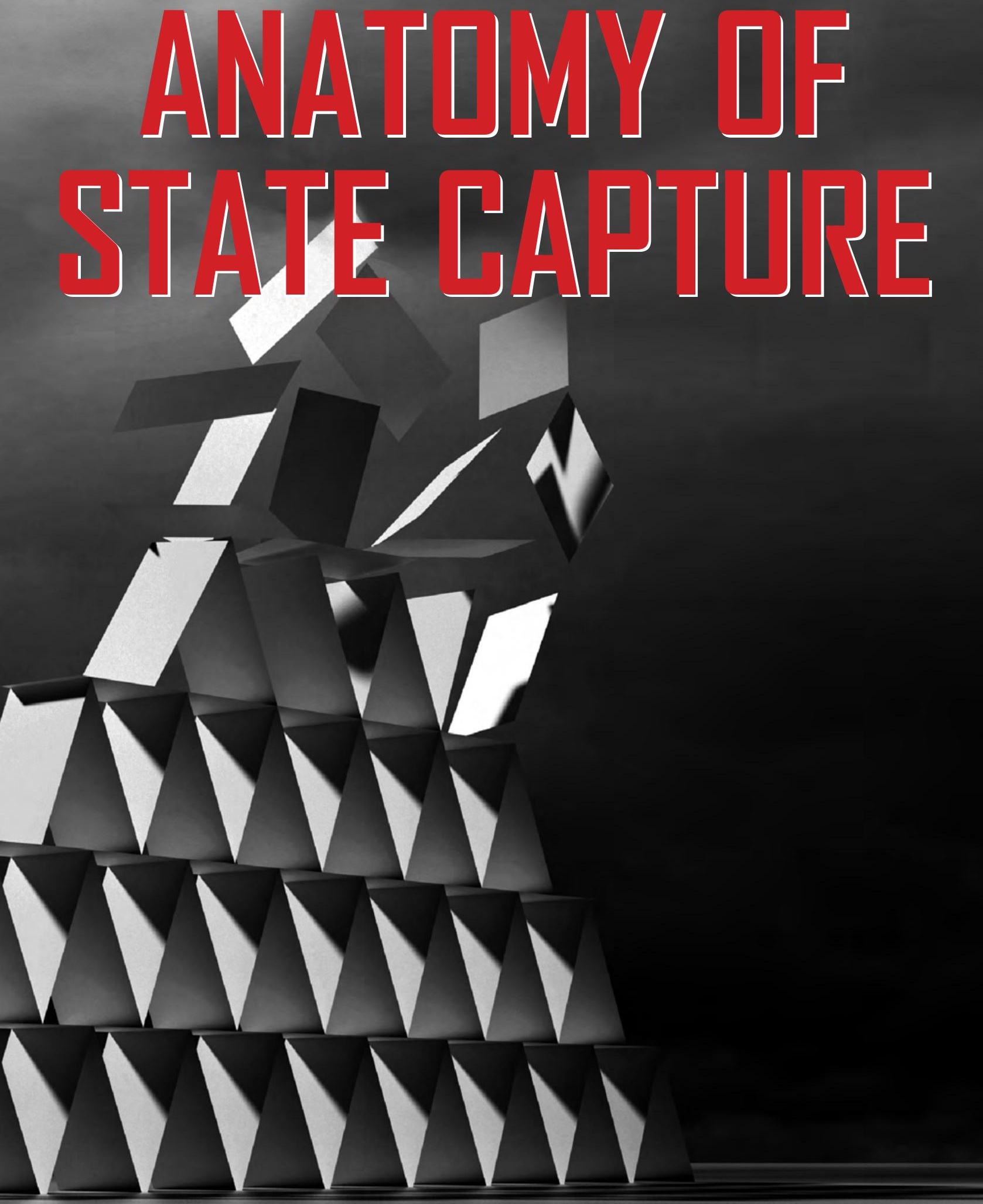

Nina Callaghan, Rabyn Foley and Mark Swilling (EDITuRS) 


\section{ANATOMY OF STATE CAPTURE: INTRODUCTION}

Nina Callaghan, Robyn Foley and Mark Swilling

\section{$1.1 \quad$ INTRODUCTION}

7 April 2017 marks a distinctive turning point in South Africa's history. It was the day of the largest nationwide protests since becoming a democracy in 1994. For the first time, members from all sectors of South African society including civil society, the private sector, religious leaders, trade unions and political opposition parties united behind one clear and succinct message: \#ZumaMustFall. Though not the first protest calling for the then President Jacob Zuma to resign (Mail \& Guardian, 2015), the events leading up to (and subsequent to) that day of mass mobilisation cemented the concept of State Capture in the nation's consciousness.

This book seeks to unpack the details of what led to this profound public outcry, and it examines the revelations that have followed, as they relate to what is now commonly referred to as State Capture.

State capture is not yet conceptually clearly defined. It is not explicitly defined in law or as a formal application to the South African experience. Even though relatively new, the concept has evolved, been adapted and supplemented over the years, rendering it in Bach's words "rather fuzzy" (Bach, 2011). The concept was first coined by Hellman, Jones and Kaufmann (2000) in a World Bank report in 2000 that provided an analysis of governance and corruption in the 'transition economies' of the former Soviet Union. For Hellman et al. (2000, p. ii), 'State Capture' manifests when there is evidence of "firms shaping and affecting formulation of the rules of the game through private payments to public officials and politicians".

For the editors and contributors to this book, this definition is too narrow and insufficient to describe the full breadth and depth of what has taken place in South Africa. A distinction must be made between the specific form of grand corruption defined as 'state capture' by Hellman et al. (2000) and the more systemic processes of State Capture that South Africa has experienced before and since 1994, and in a more pronounced way since 2007. 
We prefer a more institutional definition of State Capture derived from previous work (Bhorat, Buthelezi, Chipkin, Duma, Mondi, Peter, Qobo, Swilling \& Friedenstein, 2017; Chipkin \& Swilling, 2018), but applied beyond the so-called 'wasted nine years' following the election of Jacob Zuma as President in 2009. State Capture is best defined as a systemic process that results in the reconfiguration of political power using legal and illegal means to suit the rent-seeking purposes of a specific power elite. In South Africa, this process has been characterised, since 2009, by the formation of a shadow state directed by a power elite which operates within and parallel to the constitutional state in both formal and informal ways. The shadow state is a network of operators whose role is to facilitate the repurposing of state governance in order to derive financial and/or political benefits for a specific usually narrowly constituted power elite (Bhorat et al., 2017; Chipkin \& Swilling, 2018).

\subsection{HOW DID WE GET TO \#ZUMAMUSTFALL?}

At the end of 2017 the term "State Capture" was proclaimed as the South African word for the year, by the Pan South African Language Board (PanSALB) (Pijoos, 2017). The term found its way into the public lexicon following the release of the Public Protector's (2016) State of Capture report in November 2016. The report detailed the findings of an investigation into the alleged corrupt relationship between senior government officials at various state institutions and the Gupta family who were personally connected to then President Zuma by way of his son. The report itself does not make reference to the specific term 'state capture', but it undoubtedly reflected the alleged occurrences of grand scale corruption as defined by Hellman et al. (2000).

The 355-page report details several alleged events, actions and locations that are clear illustrations of a group of individuals leveraging political influence and institutional manipulation to irregularly, and in some cases illegally, extract rents from the state. Prime targets were State-Owned Companies (SOCs), particularly Transnet, Eskom, SAA and Denel, which have subsequently been subject to several forensic investigations by National Treasury, parliamentary inquiries and by the SOC Boards.

The Public Protector (2016) report went beyond just detailing the supposed dubious contracts and dirty dealing of the Guptas and their associates. It outlined how these deals were enabled, through the strategic placement or removal of individuals in key positions of power. Former President Zuma was clearly implicated in these deals.

Perhaps the most profound example detailed in the report was the alleged attempted bribe of then Deputy Minister of Finance, Mcebisi Jonas, by the Guptas. On 16 March 2016, in a public address to the nation, Jonas took South Africa into his confidence and confirmed the rumours that he had rejected the R600m bribe by the Guptas to 
become an agent of the shadow state after being appointed finance minister (SABC Digital News, 2016b). As shocking as these revelations were, what was revealing was the response that followed by some members of the governing party. In an interview with the South African Broadcasting Corporation (SABC), speaking on the sidelines of the Commission on the Status of Women (CSW) at the United Nations (UN) in New York on 19 March 2016, Bathabile Dlamini, then Minister of the Department of Social Development (DSD) and President of the African National Congress Women's League (ANCWL), cautioned ANC members against airing the party's dirty laundry in the media, saying: "All of us in the NEC [National Executive Committee] have our smallanyana skeletons and we don't want to take out skeletons because all hell will break loose" (SABC Digital News, 2016a).

Jonas alleged that the attempted bribe took place in August 2015, facilitated by the President's son and Gupta business partner, Duduzane Zuma, at the now infamous Gupta compound in Saxonwald (Jonas, 2018). Only a few months later on 9 December 2015, Zuma announced the removal of Nhlanhla Nene (then finance minister), replacing him with unbeknown ANC back-bencher, Des van Rooyen. This was one of several late-night cabinet re-shuffles that became a hallmark of the Zuma Presidency - ministers were moved or replaced with unclear motivations and little, if any, explanation given to the people of South Africa. It would later emerge through the various investigations, reports and public hearings that there were potentially several reasons for Zuma wanting to remove Nene. One such motive included signing off the potential trillion-rand nuclear deal with Russia. Others included pending authorisations for a much inflated Transnet contract and the formal establishment of a shelf company for Denel, the country's national arms manufacturer (Nene, 2018; PARI, 2018).

Nene's dismissal sent a shockwave through the markets, which resulted in at least R378bn being wiped off the Johannesburg Stock Exchange (JSE) and the estimated loss of some 148000 jobs (Merten, 2019). Within a few days Zuma was forced to appoint a previous Minister of Finance, Pravin Gordhan, to replace Van Rooyen (Areff, 2015). Alive to the machinations of the Guptas and their cohorts, Gordhan was an obstacle for those handling the shadow state. After unsuccessful attempts to pressure him, Zuma removed Gordhan together with Deputy Minister Jonas from office in yet another late-night cabinet reshuffle. The reshuffle presented no rational justification, especially Zuma's decision not to remove then Minister of Social Development Bathabile Dlamini. Just days earlier she had been issued a scathing rebuke from the highest court in the country for putting the payment of some 17 million beneficiaries at risk of not receiving their social grants (Chirume, Hendricks, Furlong \& DambaHendrik, 2017). 
These are just a few examples in a long list of seemingly 'irrational' and inexplicable public moments where decisions and actions by the former President and his administration were taken with seeming disregard for what was good for the country. Other seminal moments include, amongst others, the landing of the Gupta plane at Waterkloof Air Base in 2013, as well as the 2014 findings by the Public Protector in a report titled Secure in Comfort (2014) that Zuma had unduly benefited from an approximately R225m security upgrade to his Nkandla homestead.

The 7 April 2017 mass protests were a direct response to the firing of Gordhan, an action that triggered a down-grade by three rating agencies, with Standard \& Poor and Fitch moving South Africa to junk status (Van Zyl, 2017). In the months that followed, protests continued and various actions were taken in different quarters of the public to mobilise support to pressure the governing party to remove Zuma from the Presidency. Opposition parties in parliament, together with a faction of the ANC that was mobilising against the President, pressed for parliament to undertake formal inquiries into the various allegations contained in or related to the findings of the Public Protector. Civil society and religious organisations hosted events to build public awareness of the extent of the Zuma-centred power elites' exploits and 'big business' joined in the unfolding civil discourse. In response to the calls to 'connect the dots', a collective of academics formed the State Capacity Research Project (SCRP). They collaborated to formulate a conceptual framework for understanding the South African manifestation of State Capture. In May 2017, the SCRP released a report titled Betrayal of the Promise: How South Africa is being stolen (Bhorat et al., 2017).

The Betrayal of the Promise was the first academic attempt at linking the transactional and tangible acts of visible corruption with the more blurred and informal nature of state and state-like power dynamics that enabled such corruption. As highlighted by Labuschagne, the "discussions around state capture are principally done from an economic context, not from a political perspective" (2017, p. 51). It is precisely this lack of political perspective that the Betrayal of the Promise report sought to address. It not only detailed the alleged corrupt dealings of the Guptas and their facilitators in government, but also reflected on the political and social dynamics that underpinned what had happened under the Zuma administration (Bhorat et al., 2017).

The report provided key concepts that better enabled the country to recognise State Capture as a political project, rather than just a few isolated instances of grand scale corruption. These included bringing to the fore the notion of a shadow state, highlighting the critical role played by the power elite, identifying the deliberate weakening of accountability and enforcement institutions. The report outlined the pattern of State Capture to reveal the modus operandi of how various institutions were captured (Bhorat et al., 2017). 
Many of the assertions and inferences made in the Betrayal of the Promise would, only a few days after being released, be substantiated and validated through a cache of leaked emails now known as \#GuptaLeaks (2017b). The documents provided detailed evidence of shadow state operations. The leaked emails revealed tender fixing, contracts and invoices relating to various State-Owned Entities (SOEs) deals. Speeches prepared for politicians, and engagements with the PR company Bell Pottinger who pushed a disinformation campaign, were also part of the cache (\#GuptaLeaks, 2017c). The list of potentially compromised government officials grew, and connections were made between seemingly separate events. Of particular note was a flurry of meetings of key shadow state actors in Dubai during December 2015 (Cowan, 2017). The meetings seemingly followed the fallout and response to the Nene-gate debacle. What took place in Dubai still remains somewhat of a mystery. However, the investigations which flowed from the release of the State of Capture (Public Protector, 2016) report give insight into the modus operandi of the shadow state.

Present were senior officials from SOCs - Matshelo Koko [then Group Executive for Generation], Anoj Singh [Eskom CFO], Siyabonga Gama [former GCEO of Transnet], Daniel Manthsha [Chairman of Denel Board]; Gupta business associates (Duduzane Zuma, Thato and Tshepiso Magashule [both sons of then Free State Premier and current Secretary-General of the ANC, Ace Magashule], Muhammad Saloojee [former KPMG Executive Director], Fana Hlongwane, Salim Essa; former Ministers and other high ranking government, as well as political figures Mosebenzi Zwane [then Mineral Resources minister] and David (Des) van Rooyen [4-day Finance Minister] (OUTA, 2017).

The Public Protector's (2016) State of Capture report did not contain any definitive findings of guilt against specific individuals or provide for remedial actions relating to any of the allegations. Rather, the report directed that a commission of inquiry be established by the President, with the presiding judge to be determined by the Constitutional Court Chief Justice. The commission was to be afforded the same investigative powers as the public protector.

In January 2018, more than a year after the release of the Public Protectors report, Zuma (under political duress) would promulgate the establishment of the Judicial Commission of Inquiry into Allegations of State Capture, Corruption and Fraud in the Public Sector, including Organs of State, chaired by Deputy Chief Justice Raymond Zondo. The Commission is hereinafter referred to as 'the Zondo Commission' (President of Republic of South Africa, 2018).

It would be a further six months before the commission would start hearing oral testimony in August 2018. The resulting revelations detailed, in shocking terms, the 
extent and depth of the various dimensions of the shadow state and interactions with the formal legal structures of the constitutional state. The section that follows unpacks and analyses some of these revelations in greater detail, as well as those that have come from other inquiries and investigations.

\subsection{WHERE ARE WE NOW?}

At this stage, the full extent of State Capture is yet to be determined. There are ongoing investigations and commissions while fresh details of fraud, corruption and abuses of power still find their way onto the front pages of daily news. The Zondo Commission has entered its third year of hearings with many of those implicated in State Capture yet to take the stand. Since the protests of April 2017, there have been at least 28 different investigations, commissions and inquiries in the public domain. Together with several significant court cases and the trove of evidence contained in the \#Guptaleaks, they provide us with the details of well over 50 probable cases of State Capture. Each case presents its own contextual complexity and unique circumstantial nuances. However, there are certain re-occurring patterns that have emerged that inform the analysis in the chapters that follow from this introduction.

It is difficult to definitively state how many cases could be considered to be part of the State Capture project, particularly in applying the expanded definition provided above. There are several key criteria alluded to in the definition that serve as boundaries for classifying whether or not a case is valid, be it an indictment of an institution, an event or an individual.

The first criterium is the presence of those that could be considered to be part of the power elite and shadow state. These are individuals that often wield some form of influence. Political influence would include those with power to mobilise people and ideas inside and outside of government. Actors with economic influence would have access to political power brokers to attain and distribute resources. The relationships between these clusters of influence may appear to be merely transactional. However, given the clandestine nature of these transactions, high levels of trust are required for the network to operate. This is because there are often familial, tribal or historic ties that underpin the interactions of individuals within and between the various networks (Martini, 2014; Dassah, 2018; Von Holdt, 2019).

The second criterium is the use of these various forms of influence to repurpose an institution, process or system. In hindsight, it seems quite obvious when an institution has been repurposed. However, State Capture does not take place as singular events or as isolated decisions and actions. The repurposing of an institution only truly becomes visible when the damage is done and outcomes beneficial to shadow state actors become apparent. Actions and decisions taken by shadow state actors often 
appear justified and legitimate at the time they were made. However, with hindsight we recognise them as irrational and illogical from the perspective of long-term developmental policy.

\subsubsection{Motives for Capturing a State}

The primary motives for repurposing state institutions are rent extraction and the accumulation of political power. Rent seeking is the technical term that is used to refer to financial gains that are not derived from profits earned from risk-based investments or from wages/salaries. These gains are not illegal or even immoral in and of themselves. They can include, for example, subsidies to incentivise certain kinds of investments, or housing subsidies for the poor, or even procurement preferences. However, when rent seeking results in gains made by those who have influenced decisions to allocate rents to benefit themselves, the end result is corrupt rent seeking that can lead ultimately into systemic State Capture, although this is not inevitable.

However, rent seeking and rent extraction may just be a means for accumulating political power to entrench and deepen the power position of a particular power elite, or vice versa, i.e., accumulation of political power becomes a means for rapid enrichment. It is not always easy to distinguish between rent extraction and political power, especially when it comes to identifying motivations for repurposing state institutions. However, in general, they enable each other: for some in the network, it is mainly about the accumulation of political power to maintain the conditions for rent-seeking over time, while for others with a shorter time horizon and more opportunistic strategic sensibility it is mainly about maximising the opportunities for rent-seeking while the conditions are appropriate.

There are many other reasons and ways to repurpose institutions, a prime example being the hollowing out of law enforcement bodies to ensure that those in the network are protected against prosecution. Another example is the use of the State Security Agency (SSA) to spy on political opponents (High-Level Review Panel on the SSA, 2018). This form of repurposing seeks to weaken accountability and minimise the overall personal risk to corrupted individuals operating within the network. The operators themselves in these kinds of processes might benefit from the crumbs that fall off the table but are rarely the big players.

A third motive for the repurposing of institutions is maintaining legitimacy. This is one of the key elements that differentiates State Capture as experienced in South Africa from being merely a form of grand corruption. It is one of the reasons why it is argued that State Capture was a political project and not just a collection of events with stand-alone ends. There are two key elements to maintaining legitimacy within a democratic state that suffers the consequences of State Capture. The first is 
to hide (and ultimately deny) the actions of the shadow state and the second is about controlling the narrative through throttling information. This is in part achieved by weakening institutions that would hold those in power to account. For example, the Chief Operations Officer of the South African National Broadcaster (SABC) Hlaudi Motsoeneng instructed the news team not to show the destruction of property during service delivery protests in mid 2016 (Ad Hoc Committee on the SABC Board Inquiry, 2017; Zondo Commission, 2019b).

This decision affected the public's ability to fully comprehend the scale or extent of the protests, shaping the story to downplay the levels of anger and dissatisfaction of communities. Another example of controlling the narrative was when the Guptas established their own media company made up of The New Age newspaper and a 24-hour television news channel called ANN7. At his first appearance at the Zondo Commission, Zuma openly admitted that the media company was actually his idea for the specific purpose of celebrating what he called the positive developments and achievements of the state (Zondo Commission, 2019a). The shadow state also deployed mis- and disinformation campaigns, crafted by UK-owned public relations company Bell Pottinger to influence public perception and shape opinion (\#GuptaLeaks, 2017c).

The shadow state derives its power and resources from the constitutional state, a relationship that is, ultimately, politically unsustainable - especially if the predatory capabilities of the shadow state are allowed to expand in an unmanageable way (Khan, 2000; Grzymala-Busse, 2008; Richards, 2008; Di John, 2010; Gray \& Whitfield, 2014). In the case of State Capture in South Africa, the constitutional state has been hollowed out as the energy and objectives of governance were redirected to serve or defend the shadow state. The result was an abandoned social contract and a neglected development agenda for the working class and poor. The maintenance of legitimacy became a strenuous farce that further hollowed out the constitutional state, decimating any faith the voting public could have in participating in a meaningful political life. However, to artificially maintain legitimacy, the shadow state requires longevity, including all that is required to deny and therefore transcend consequences of weakening governance, growing social conflict and declining economic growth rates.

It needs to be stressed that each of these motives for repurposing institutions are not independent of each other. For example, part of the reason for extracting rents is to fund patronage networks and mobilise political support, which in turn maintains legitimacy. Weakening accountability reduces risk for extracting rents while simultaneously improving the prospects of maintaining legitimacy. However, in the end the internal contradictions of the State Capture project are unavoidable. As governance collapses and the economy disintegrates, the predatory nature of the 
shadow state becomes increasingly obvious which, in turn, triggers the backlash that challenges those who are perceived to be responsible for State Capture.

\subsubsection{The Extent of State Capture}

As already indicated, we have tracked more than 28 major investigations, commissions and inquiries (see Appendix on page 403). A significant number of these investigations were triggered by the political fallout subsequent to April 2017 where calls for accountability could no longer fall on deaf ears. From the details contained in the various reports, public hearings, court cases and investigative reporting by journalists, it can be readily observed that State Capture is not as simple as the former President believes, having said, "it's a few people who did something somewhere". The State Capture project that has emerged in South Africa is multi-levelled, multi-layered, multi-nodal and multi-targeted.

From the information revealed to date, State Capture stretches across the country and beyond. Seven out of the nine provinces have been directly implicated and it has occurred at the lowest level of government. The prime example of this is the Vrede Dairy Farm scandal where money meant to be invested in the development of previously disadvantaged prospective farmers was looted to pay for the infamous Sun City Gupta wedding (\#GuptaLeaks, 2017a; Shadow World Investigations, 2019).

At least 13 national level ministries and more than 15 of the most socially and economically crucial SOEs have been central to the State Capture project. The strategic institutions that were captured range from SOCs providing critical economic services (energy, transportation and infrastructure development), to the various law enforcement agencies and government entities that provide crucial social services. Each institution can be considered to have been repurposed in line with one or more of the motives, as described in the previous section.

Eskom, Transnet, SAA and Denel are capital intensive and have large operations budgets, making them prime sites for the extraction of rents and hence central targets for the Guptas. These institutions present the most visible and tangible aspect of the kind of State Capture that aligns with the traditional understanding, namely grand scale corruption. There are instances where policies have been formulated to enable the legal extraction of rents, for example: as minister of Public Enterprises, Malusi Gigaba was insistent that Eskom must award the majority of its coal supplier contacts to firms with 50\%+1 black ownership (Eskom, 2016; Godinho \& Hermanus, 2018). There is nothing wrong with this in and of itself. However, when this policy was coupled with the awarding of contracts to black-owned companies that paid off the Guptas to get the contract, then this is corrupt rent-seeking. 


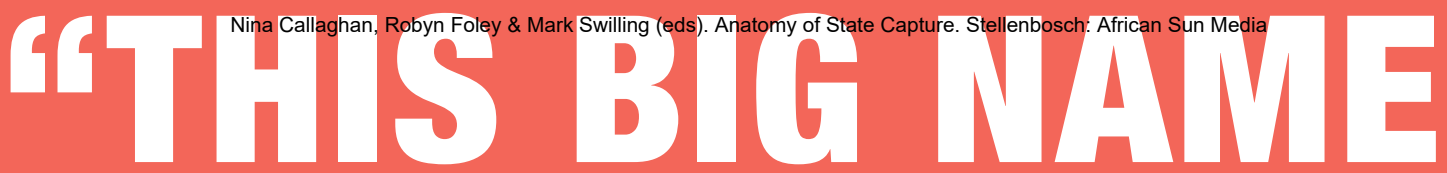

\section{Highlights of a subverted state 1999 to 2018}

J99 Jacob Zuma is appointed Deputy President of South Africa.

'11 Guptas meet Zuma at a Sahara function.

'02 Bosasa gets into bed with Government Known for their apartheid activism \& strong ties to high-profile ANC comrades like Zuma, the Watsons expand their Bosasa operation from
servicing mining operations to procuring further lucrative government contracts i.e. home affairs, correctional services, the post office, social development etc. The bribes expand accordingly. Over the next 18 years Bosasa will access over R12bn worth of irregular government contracts with 100 s of millions going towards bribing corrupt government officials.

'03 Zuma Implicated in Arms Deal

He is fingered in the R30bn corrupt Arms Deal (that has actually cost $+/$-R65bn to date), however Director of National Prosecuting Authority Bulelani Ngcuka says, that even though they have a prima facie case against him, the prospects of a successful prosecution are slim \& only Zuma's advisor, Schabir Shaik is charged with corruption, fraud \& tax evasion.

'04 Alleged Bribes

Zuma becomes a key figure in Schabir Shaik's corruption trial, with alleged bribes \& payments Shaik \& his companies made to Zuma.

'05 Mbeki Dismisses Zuma

Shaik is sentenced to 15 years for corruption. Charges are eventually brought against Zuma over the Arms Deal. He is also charged for raping a 31-year-old family friend, Fezekile Ntsukela Kuzwayo. Based on these charges, President Thabo Mbeki dismisses Zuma as Deputy President.

\section{'05 Mdluli deployed}

Zuma supporter, Richard Mdluli, is appointed Deputy Provincial Police Commissioner of Gauteng. He later oversees the detectives who investigate Zuma's rape case in 2006 \& also heads up investigations into the Scorpions who are investigating Zuma's corruption charges.

\section{Zuma is let off the hook}

Zuma is acquitted of rape charges \& the Arms Deal charges against him are struck from the role due to botched prosecution efforts.

\section{'07 Zuma elected ANC President}

After an arduous ANC power struggle full of conspiracies, Spy allegations \& prosecutorial to-ing \& fro-ing between Mbeki \& Zuma, Zuma is elected ANC President. Shortly after, Zuma's Arms Deal corruption charges are reinstated.

\section{'08 Mbeki out}

Thabo Mbeki is forced to resign due to his controversial interference in the NPA around the prosecution of Zuma. Zuma supporting Kgalema Motlanthe takes over as president of SA \& appoints a number of Zuma loyalists to key positions, including Mokotedi Mpshe as Acting National Director of Public Prosecutions (NDPP).

\section{'09 Scorpions disbanded}

Scorpions are replaced by the Hawks. At the same time "Spy Tapes" surface \& the renewed corruption charges against Zuma are withdrawn by Mokotedi Mpshe shortly before national elections.

39

Zuma becomes President of South Africa

He swiftly ensures the criminal justice system offers him \& his friends impunity with a number of new questionable/irregular appointments. These include: Richard Mdluli as Head of SAPS Crime Intelligence Division, Menzi Simelane as Head of Public Prosecutions, \& a previously suspended Nomgcobo Jiba is appointed Deputy National Director of Public Prosecutions.

\section{'09 The Saxonwold Shebeen}

0 akbay gives jobs to Zuma family. Meetings at the Gupta Saxonwald residence between the Guptas \& Zuma, his family \& fellow shadow state cronies become so prevalent that the compound becomes known as "The Saxonwold Shebeen" - these notorious meetings are later confirmed when the "Gupta Leaks" come out.

'10 1st motion of no confidence against Zuma Amended to full confidence by majority of Parliament.

\section{Zuma's first cabinet reshuffle}

Most notable deployment of cadres are Bathabile Dlamini as Minister of Social Development (oversees repurposing of SASSA) \& Malusi Gigaba as Minister of Public Enterprises (oversees repurposing of Transnet, Eskom \& Denel).

${ }^{10}$ The R2 Trillion Nuclear deal that almost happened Gupta-linked company Oakbay together with IDC \& Duduzane Zuma's company purchase the 'Dominion' uranium mine. Afterwards the 1st Integrated Resource Plan (IRP) reveals a 9,6 GW nuclear programme to be operational by 2030 . The IRP undergoes 4 iterations over the next 8 years without critical public participation. Zuma takes a personal interest in controlling the Nuclear Deal by chairing various parliamentary nuclear coordination committees. He also visits Russia an unprecedented 7 times, where he personally (often privately) pushes Nuclear Deal arrangements forward with Putin. The estimated R2tn Nuclear Deal almost gets through till Nhianhia Nene refuses to sign the state guarantee
with Russia. Nene is then fired by Zuma. Just the exercise of trying to push the unconstitutional Nuclear Deal through costs SA tax payers millions.

\section{Sunday Times' "Death Squad" fake} news report

An article states that Anwa Dramat \& Hawks Gauteng Head Shadrack Sibiya are allegedly involved in the illegal handing over of six Zimbabweans to Zimbabwean police. Later in the year the paper alleges Hawks KwaZulu-Natal, Cato Manor Organised Crime Unit Head Johan Booysen is complicit in the extra-judicial execution of numerous crime suspects - Booysen was investigating Zuma ally, Thoshan Panday at the time.
11

Mdluli's 6 years free pay

Zuma appoints Lawrence Mrwebi as Special

Director of Public Prosecutions \& Head of Specialised Commercial Crime Unit. Mrwebi goes on to withdraw charges against Mdluli \& Mdluli is reinstated Head of SAPS Crime Intelligence Division. Mdluli is soon suspended again \& gets full pay plus benefits for the next 6 years without any disciplinary action ever taken. This becomes a fashion for many of Zuma's comrades who are caught in the act.

11 SASSA grants hijacked

Zuma's newly appointed Minister of DSD Bathabile Dlamini, Tom Moyane \& SASSA CEO Virginia Petersen oversee the specification for the grant from 'PREFERRED' to 'MUST' ensuring CPS is the only valid contender. With the help of scores of dodgy BEE partners \& shadow state 'work streams' CPS/Net1 irregularly win the bid to servic grant beneficiary payments for the next 8 years, extracting over R1.5bn in profit, of which R316m is for an irregular payment of re-registrations this excludes the estimated R800m + that is unethically taken from grant beneficiaries in irregular/ unauthorised deductions on their grants. We can't say who actually benefited from these profits but as Dlamini confesses, "Those that made profit through CPS through by their wives are known, but because they are well respected by the organization. Nothing has been said to them.

\section{1}

Bain helps hollow out SOEs

Telkom CEO Sipho Maseko introduces Bain \& Co consultant Vittorio Massone to Zuma. Vittorio presents 'Project Phoenix' \& consults Zuma on reshaping South Africa's economy, communications, energy \& implementing the shadow state agenda. Massone meets Tom Moyane in 2013 $\&$ coaches him on the 'first 100 days' of 'SARS $2.0^{\prime}$ restructuring/take-over plan prior to his appointment. Once Moyane is CEO of SARS Bain is contracted to help implement the restructuring/ capture of SARS. They are payed +/-R200m for this.

'12

\section{Hlaudi repurposes SABC}

Dec 2011 Zuma \& Gupta's close ally Hlaud Motsoeneng is appointed acting $\mathrm{COO}$ of SABC. He illegally (without even a metric), becomes official COO in 2012 \& starts causing havoc. Dodgy deals, outrageous bonuses \& bungled actions cost the SABC over R560 million alone. More damaging is how he interfered with editorial decisions l.e. blocked ANC opposition party news, as well as mass protests that showed Zuma's ANC in a bad light, forced reporters to cover political cadres \& fired anyone who apposed him.

\section{The looting of Transnet}

After a litany of dodgy dealings at Telkom Brian A Malusi Gigaba \& fellow fixers Anoj Singh, Siyabonga Gama \& Iqbal Sharma he initiates the lavish Market Demand Strategy (MDS), a 7 year investment plan with a R420bn budget \& one of state capture's biggest looting operations begins. It is later identified that between 2013-2018 Transnet spent a total of R37bn on contracts with direct links to the Guptas \& state capture, amounting to $60 \%$ of the SEO's CapEx, \& $10 \%$ of its total revenue. Together Liebherr, CSR, CNR, SAP, ZPMC, Neotel, Software AG \& other complicit companies payed kickbacks totalling R7.7bn for the lucrative contrac 


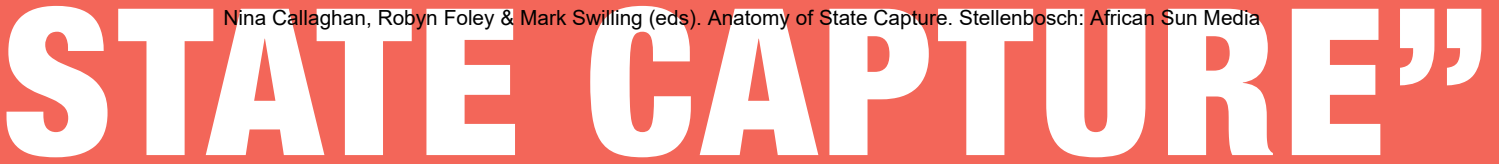

112

SAA quietly goes insolvent

PWC \& Nkonki Inc. are irregularly contracted to audit SAA from 2011 to 2015. Zuma Foundation Chairperson, Dudu Myene Chairs the SAA board over the period \& even though there is much speculation of corruption the embattled national airine consistentily receives ciean audits. Just before Nene is tired he gets the Audititer General to
step in. In 2017 AGSA finds SAA's self proclaimed irregular expenditure of R125m actually stands at R4.5bn with 103 of the 140 contracts probed being found to have irregular expenditure.

113 The New Age \& ANN7 misinformation machine

Zuma's propaganda idea is realised in 2010 when Guptas launch TNA Media's first edition of The New Age newspaper. The media house later expands to include the notoriously biased ANN7 TV channel in 2013. Both media platforms are used to syphon millions out of various $\mathrm{SOEs}$ (including the $\mathrm{SABC}$ ) via dodgy multi-million Rand breakfast events \& forced media-buys. Main function though is to push the shadow state propaganda \& discredit opposition with fake news.

\section{'13 Waterkloof Airforce Base scandal}

A private plane with Gupta family wedding guests lands at Waterkloof Air Force Base. The unprecedented landing is cleared on instruction from "Number One". The lavish R30m wedding itself is paid for from looting the R220m Free State Vrede Dairy Project.

Zuma's 5th cabinet reshuffle

Notably Ben Martins moves from Minister of Transport to Department of Energy where he issues the first determination 34 for the Nuclear Deal.

\section{'14 Zuma round 2}

Even with Waterkloof \& Nkandla scandals playing out Zuma is re-elected President of SA. He introduces new Ministers Faith Muthambi as Minister of Communications (oversees repurposing of SABC with Hlaudi Motsoneng), David Mahlobo as Minister of State Security (oversees repurposing of SSA) \& Nomvula Mokonyane as Minister of Water \& Sanitation (Bosasa's political conduit). Moves Tina Joemat Pettersson to Minister of Energy (signs nuclear agreement with Russia). Gigaba to Home Affairs (arranges naturalisation \& visas for Guptas \& friends), Lynne Brown takes over Public Enterprises (moves rent extractors Brian Molefe \& Anoj Singh from Transnet to Eskom).

\section{SA in dark with load shedding}

Malusi Gigaba becomes Minister of Public
Enterprises in 2010 \& Eskom sees Zola Tsotsi \& a
gang of shadow state operatives \& enablers enter
the picture. Billions are looted in irregular contracts
linked to Gupta \& Duduzane Zuma companies.
When Lynn Brown takes over in 2014 she deploys
Molefe \& Singh \& the capturing expands to
extorting \& highjacking external coal suppliers like
Glecor's Optimum Coal Mine. The corrupt deals,
misgoverned expenditure and hollowing out of
Eskom resulted in lost institutional knowledge, load
shedding and exhorbitant annual tariff increase that
citizens and the economy had to absorb caused
by a decade of stagnant policy and infrastructure
direction. This cost is estimated to be around
R338bn over 10 years.

\section{Spies lies \& the 'Rogue Unit' narrative} When SARS High Risk Investigation Unit (HRIU) starts looking into Zuma \& his cronies, unconfirmed stories around the unit are leaked to the Sunday times. Based on these 'stories' Minister of State Security David Mahlobo gets the Inspector General of Intelligence to investigate. The investigations are taken even further when Tom Moyani takes the helm of SARS. He uses the evolving Sunday Times "Rogue Unit" story to dissolve the HRIU and abandon its high profile cases. After that KPMG is brought in (overseen by Johnas Makwakwa) to probe even deeper still, shifting the narrative to focus on Pravin Gordhan, Pillay \& others in order to provide Head of NPA Shaun 'the sheep' Abrahams with material to prosecute. Even after Sunday Times has admitted to poor reporting \& both the NPA \& KPMG have withdrawn charges \& findings respectively, Zuma's new Public Protector Busisiwe Mkhwebane insists on resurrecting the narrative \& tries numerous times to discredit Gordhan \& c0, squandering millions of tax payers money with ongoing court proceedings.

15

2nd motion of no confidence against Zuma is withdrawn.

15 3rd motion of no confidence against Zuma is voted down in Parliament.

15

5 Zuma's 6th cabinet reshuffle

Mosebenzi Zwane is appointed Minister of Mineral Resources (facilitates the Gupta's mine take-over at Glencore Optimum).

315 Nene-Gate

After Nene refuses to sign off the SAA deal \& the nuclear state guarantee with Russia, Mcebisi Jonas is approached by the Guptas \& offered a R600m bribe to become 'their' new Minister of Finance. Jonas informs Nene. Zuma fires Nene $\&$ appoints Des van Rooyen. Result: financial markets react, causing inflation to rise from R14.59 to R15.90 in just 3 days, costing the SA economy over R500bn in equities alone.

'16 Public Protector Thuli Modonsela's State of Capture Report is released.

316 4th motion of no confidence against Zuma Voted down in Parliament. Then after Nene-Gate a Section 89 motion (impeachment) to remove Zuma is voted down in parliament. Later a 5th motion of no confidence against Zuma is also voted down in parliament.

\section{Bell Pottinger spins out of control}

When Oakbay is drawing too much attention in 2016 around state capture suspicions, Bell Pottinger is pulled in to divert attention \& are paid a $£ 100,000$ a month to change the narrative to help push the Zuma-Gupta agenda. The UK-based PR company spins the white monopoly capital campaign, inciting and heightening existing cultural and racial tensions. The white monopoly capital narrative is used to smear Gordhan \& legitimise Zuma firing him.

\section{'16 Zuma's Nkandla upgrades}

The Constitutional Court delivers its judgment on the over R246m Nkandla upgrades that had been ongoing on since 2010. The court rules that the powers of the Public Protector are binding \& that Zuma has to pay back some of the money for his R3.9m 'fire pool' \& other upgrades.

17 6th motion of no confidence against Zuma Delayed due to secret ballot request but later voted down in Parliament (even with secret vote).

11 Zuma's 8th cabinet reshuffle - Gordhan fired Based on a 'badly written' conspiratorial 'intelligence report' \& the 'white monopoly capital' narrative Zuma fires Gordhan \& his deputy, Mcebisi Jonas. Gigaba becomes new Finance Minister \& the SA Rand drops $7.7 \%$ in less than a week, effecting Standard \& Poor's downgrade to junk status. It is estimated that Gordhan and Jonas's axing cost the country over R250bn to date \& we are still feeling the effects to this day.

\section{Zuma's 9th cabinet reshuffle}

David Mahlobo is moved to Minister of Energy (revives push for Nuclear Deal). He is replaced by Bongani Bongo as Minister of State Security (attempts to bribe parliamentary officer overseeing enquiry into state capture at Eskom).

\section{SASSA-Gate}

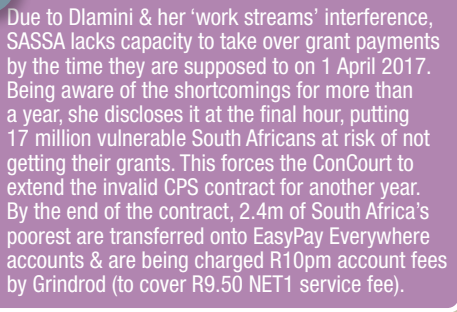

by Grindrod (to cover R9.50 NET1 service fee).

\section{Zuma's Public Protector}

Zuma appoints Busisiwe Mkhwebane as his new Public Protector in 2016. Even after Zuma's ousting, she continues to protect the shadow state agenda by exonerateing key figures, Magashule, Mosebenzi Zwane \& the Guptas in her Vrede Dairy Project report in 2018. She also goes out of her way to persecute Gordhan by resurrecting nullified allegations including the "Rogue Unit" narrative. Most of the state capture related enquiries/reports in her office have still not seen the light of day (Nov 2020).

\section{Zuma out}

Zuma resigns the day before a 7 th motion of no confidence is brought against him (ANC MPS say they will vote him out if he doesn't quit).

\section{Key turning Maintaining points legitimacy \\ Weakening accountability \\ Extracting}

\section{UNIVERSAL GRAPHICS KEY}


The majority of the time, however, rent extraction still entailed the manipulation and subversion of procurement processes. This included having prior knowledge of (or a hand in developing) bid specifications, influence in the bid evaluation or adjudication committees or influencing the authorising party (be it the CEO or Board) to favour a particular party. There are multiple ways in which the procurement processes, as guided by the Public Finance Management Act (PFMA), have been subverted to enable large-scale looting of public institutions.

Perhaps one of the major stumbling blocks to the project of rent extraction and complete control of the public purse, was the oversight role played by National Treasury. The cabinet reshuffles of Nene and Gordhan, both occurred at pivotal moments when Treasury refused to sign off on large deals or challenged the Zumacentred power elites.

Government institutions only represent one side of the corrupt and clandestine transactions. The role played by various companies within the private sector need to be highlighted and equally scrutinised. Many cases of State Capture entailed large scale international firms buying into the kick-back schemes, inflating costs to South Africa and in some instances facilitating the looting of the state. The likes of SAP, T-Systems, China South Rail, Net1, etc. - all internationally based - have derived significant financial benefit and have faced little to no consequence for their involvement in State Capture.

Certain private sector firms were also a critical part of weakening accountability and facilitating the extraction of rents. These are the auditors, consultants, lawyers and bankers that have assisted by providing a veil of legitimacy to mask the true nature of deals struck, facilitating movement of money and turning a blind eye to the dirty deals and 'irregularities' that they should in fact have called out. Most of the 'Big Four' international auditing firms have to some extent been implicated, namely KPMG, Deloitte and PwC (Abedian \& Mantell, 2017; Cameron, 2019; Davis, 2020a). Various international consultancies have received excessively lucrative contracts for services that could/should have been undertaken by the institutions themselves or that in some instances were not necessarily required. These include the likes of Bain \& Company, McKinsey and Gartner, as well as a group of local 'management' consultancies such as Regiments, Trillian and Rangewave.

A pivotal task of weakening accountability entailed the capture of the criminal justice system. This included repurposing of law enforcement and entities responsible for state security to shield the shadow state from facing criminal prosecution. The SAPS, Hawks, NPA and state security were central to the State Capture project. The ramifications of the hollowing out of these institutions is that government's overall 
ability to enforce the rule of law has been greatly compromised. It is little wonder then that other white-collar criminal elements not connected to the shadow state and those responsible for major corporate scandals (such as Steinhoff, Tongaat Hulett and $\mathrm{EOH}$ ) have not been called to book (BusinessTech, 2019; Business Insider SA, 2020).

Accountability extends beyond legal requirements of what can be considered criminal and there are several other state institutions that play a role in holding those in power to account. This is one of the main responsibilities of the legislature and the various Chapter 9 institutions, such as the Public Protector. Discussed in more detail below, the extent to which the National Assembly was captured is at this stage debatable. However, it is worth remembering that over the nine years of Zuma's reign there were several attempts by the opposition to table a vote of no confidence in his leadership. He emerged vindicated and emboldened after each failed motion (Wilkinson \& Africa Check, 2017). The Constitutional Court scathingly rebuked parliament for supporting the white-wash fire-pool report produced to justify the R245m security upgrades to Zuma's Nkandla homestead. As argued in the judgment (Constitutional Court of South Africa, 2016, pp. 48 \& 51):

In principle, there may have been nothing wrong with those "parallel" processes. But, there was everything wrong with the National Assembly stepping into the shoes of the Public Protector, by passing a resolution that purported effectively to nullify the findings made and remedial action taken by the Public Protector and replacing them with its own findings and "remedial action". This, the rule of law is dead against. It is another way of taking the law into one's hands and thus constitutes self-help...

... the failure by the National Assembly to hold the President accountable by ensuring that he complies with the remedial action taken against him, is inconsistent with its obligations to scrutinise and oversee executive action and to maintain oversight of the exercise of executive powers by the President.

Though it cannot be stated outright that there are no elements in the judiciary that are aligned with the shadow state, the number of significant court rulings thwarting and correcting the intended abuses of power needs to be applauded. Significant examples over and above the already mentioned Nkandla saga include the Constitutional Court intervention in the SASSA-Gate crisis and the High Court putting a stop to the Russian nuclear deal. There are many other examples, but these best illustrate the importance of ensuring that the different arms of government operate with independence.

There are two other sectors in society that play a crucial role in ensuring we have a functional democracy, namely a free and independent media and a robust civil society. Ultimately, at least in theory, within a constitutional democracy all those in positions of power should be accountable to the citizenry. The task of news media is to inform 
citizens of how government is performing (or not as the case might be) and one of the functions for civil society is to give voice to citizen responses to government's performance.

Over the years, various civil society organisations have been instrumental in curtailing the extent of the damage that could have materialised from the machinations of the shadow state. Examples can be readily found in the two court cases already mentioned. The Black Sash Trust initiated the Constitutional Court case that saw Minister Dlamini reprimanded for putting 17 million social grant beneficiaries at risk of not receiving what for many was their only source of income and means of survival (Pijoos, 2018). Earthlife Africa and the Southern African Faith Communities' Environment Institute jointly took on the government's plan to ram through the Russian nuclear deal, saving the country from committing future generations to paying off the massive bill estimated at R1tn (Gosling, 2018).

There are many other cases that should be included in this analysis. One, however, is particularly noteworthy. This involved the case brought to the Constitutional Court by Corruption Watch, Freedom Under Law (FUL) and Council for the Advancement of the South African Constitution (CASAC). The case challenged the then President Zuma's appointment of Shaun Abrahams as National Director of Public Prosecutions (NDPP) following the coerced departure of the previous incumbent Mxolisi Nxasana. The Court ruled that Nxasana's removal was an abuse of power and that the appointment of Abrahams was therefore unlawful, as clearly stated (Constitutional Court of South Africa, 2018):

Former President Zuma appointed Advocate Abrahams following his unlawful removal of Mr Nxasana. That removal was an abuse of power. Advocate Abrahams benefitted from this abuse of power. It matters not that he may have been unaware of the abuse of power; the rule of law dictates that the office of NDPP be cleansed of all the ills that have plagued it for the past few years.

The investigations by relentless groups of investigative journalists have been instrumental in unravelling State Capture. By asking the tough questions and probing beyond the surface level platitudes provided by the power elite, these journalists were able to shine a light on the shadow state. The role the media plays is, however, a double-edged sword. The use and manipulation of the media to spread dis- and misinformation against shadow state opponents, was rightfully assessed as being a central tool for maintaining the legitimacy of the shadow state.

South Africans, like the rest of the world, are faced with the challenge of being bombarded by 'fake news', the rise of gutter populism and the nameless, faceless onslaught of deliberate untruths used to drive hate and stir up division. This use of the media 
(and particularly social media) can most readily be seen in the antics of Bell Pottinger (think White Monopoly Capital [WMC] and Radical Economic Transformation [RET]) and the 'good news' stories peddled by the Gupta-owned The New Age and ANN7 (both of which were established as a result of a 'suggestion' from Zuma [Zondo Commission, 2019a]). The shadow state also astutely used various forms of 'active measures', such as creating and leaking of salacious stories to journalists that were later used to remove obstacles and drive narratives (the SARS 'rogue unit' case is an example).

These propaganda tactics are not new. However, the overarching goal is no longer just about driving a specific agenda. Rather, as seen in the 'fightback campaign' and growing worldwide authoritarian populist movement, elites tend to focus on creating an environment that obscures and supports illegitimacy (post-truth politics) where facts no longer matter and all that counts is who can tap into the frustrations of the masses (real or constructed) and/or entertain the most (Abrams, 2016; Lewandowsky, Ecker \& Cook, 2017). Fake news and disinformation campaigns have the effect of paralysing ordinary people's sense of agency and trust, contributing to what Timothy Snyder calls the politics of inevitability, "the idea that there are no ideas ... that there are no alternatives" (Snyder, 2018, p. 15). Intentionally created doubt becomes the virus that infects the entire body-politic, ultimately draining out the vitality of democratic ideals.

The last critical element to maintaining legitimacy lies in the democratic system itself - the logics of patronage and clientelism that are embedded in our current political system (Van de Walle, 2007; Anciano, 2018). Those that enjoy the windfalls derived from the extraction of rents - the Oakbay's, BOSASA's and Trillian's - funnel a proportion of their wealth into bolstering the political legitimacy of the power elite and justifying the actions of the shadow state. In return they are protected from scrutiny and prosecution, in effect a political protection racket for the corrupt. It is an underlying logic of predatory power and is perhaps most eloquently presented in a quote, which is attributed to former Brazilian President Getulio Vargas (1930-45, 1950-54), "For my friends, everything; for my enemies, the law" (O’Donnell, 2004, p. 40).

Literally hundreds of individuals and organisations have been implicated in the State Capture project. By the end of 2019, the Zondo Commission had issued more than 700 notifications to implicated parties; the commission was set to continue until March 2021 (Davis, 2020b; Wicks, 2020). Although the Gupta network was the central focus of the State of Capture report (Public Protector, 2016), the various investigations reveal that there are several other networks entangled in the State Capture project. These networks operate semi-independently of one another but remain interconnected by the power elites. At the beginning of 2019, South Africans were aghast at the testimony 
that was presented by Angelo Agrizzi at the Zondo Commission. Video evidence of Gavin Watson counting out bundles of hundred rand notes for bribes and kickbacks relating to billion-rand tenders awarded to BOSASA helped illustrate the networks and characters involved. This is but one network and there are many more, as will be presented in this book.

\subsubsection{The Cost of State Capture}

As the full extent is yet to be determined, trying to definitively calculate the full cost of State Capture is at best speculative. However, as the stories have unfolded over time the estimates have successively increased over the years. For Former Finance Minister Pravin Gordhan it cost between R250bn in 2017 (The Citizen, 2017), increasing to R500bn as stated by President Ramaphosa in 2019 (Omarjee, 2019). These amounts may be the direct cost of moneys lost from the state, but journalist Marianne Merten pegs the indirect loss could be far greater, estimating it at "around R1.5tn over the second term of the Jacob Zuma administration" (Merten, 2019).

We argue that these types of cost calculations are far too narrow when we reflect on the true extent of the impacts State Capture has had on the nation. One needs only to consider the 'opportunity costs'. Cyril Ramaphosa referred to "nine wasted years" (Haffajee, 2019), but the cost of that lost time is yet to be adequately determined. David Fowkes, a lead economist for regional policy at SARB has noted that "in a normally functioning economy, growth should be over $4 \%$ [given SA's level of investment] and there certainly hasn't been growth ... This is the evidence of what state capture looks like ... Where you have major investment and no growth" (Magubane, 2019). The country faces a fiscal quagmire where we now have government debt and government revenue collection falling short year on year. Overall there has been a negative impact on the country's economic growth potential, due to policy uncertainty and instability, the rating downgrades and increased rates in financial outflows, as well as the negative ramification thereof such as rising unemployment and growing inequality (Hosken, 2017; Hofstatter, 2018; Makhafola, 2018).

Then there are the incalculable personal costs that the State Capture project has incurred on the many individuals whose careers and livelihoods have been decimated. This includes the trauma associated with intimidation and coercive acts they were forced to endure in order to keep their jobs. Many of those who attempted to push back and reveal the truth lost their jobs and reputation. The erosion of government's ability to meet the basic service delivery objectives or fulfil its constitutional obligations cannot be decoupled from the State Capture project. The struggle to access and control state resources at local levels has led to an increase in political violence in the country. The tragedy of Life Esidimeni (Moseneke, 2018; Mitchley, 2019) and 
the rise in political killings in KwaZulu-Natal (KZN), as detailed in the Moerance Commission (Moerane, Gounden \& Potgieter, 2018), did not occur in isolation from the political and economic context (Von Holdt, 2019). Corruption and State Capture is not a victimless crime and future generations will have to pay for it.

\subsubsection{The Modus Operandi}

In terms of the modus operandi for "capturing" a government institution, the shadow state undertakes the following tasks or actions from within the government itself:

- Securing control over the public service, in particular through the appointment of Cabinet Ministers, Board Directors, Heads of strategic agencies, etc.

- Intentionally weakening key technical institutions and formal executive processes. This often entails:

- removing key top officials and replacing them with people who would not obstruct the objectives of the shadow state;

- having officials serve only in acting positions (limiting their ability to take long-term strategic decisions);

- $\quad$ appointing external advisors; and

" deploying persons ("fixers") to intervene in the procurement process.

- Securing access to opportunities for repurposing the state by manipulating or changing the directives or objectives of the government:

- In cases where the shadow state objectives are for the purposes of accruing wealth, this often centres around large-scale projects/contracts.

" There is often an element of "scope creep" in the contract, where the value is increased or the contract is extended, potentially indefinitely.

- Creating parallel political, governmental and decision-making structures that undermine the functional operation of government institutions.

In the private sector, there are many different strategies and tactics that can be deployed. However, the pattern is clear:

- The companies which are awarded the contracts are either:

- recently established (start-ups, with little experience or capacity to undertake the contractual obligations);

- complex joint ventures, with very little background/clarity of ownership or capability (BBEEE deals often fall within this category); or

- newly acquired reputable and established companies (business owners either sell or are pushed out of their companies - experiences of hostile takeovers). 
- Behind formal (often legal) contract agreements, are the 'brokers/middlemen' who broker the deals, where often wealth is accumulated through lucrative BEEE partnerships entered into with a private sector company and then distributed across the informal network of the power elites.

- There is often a concerted effort, by those in the shadow state, to stifle or remove the competition or critics of the shadow state operations.

\subsubsection{The Functions and Structure of the Shadow State}

The formation of the shadow state is made possible by a host of actors who collaborate in various ways to realise their goas. These include:

- Political Elites: government Ministers, Presidential and Executive appointees and Members of Parliament (MPs). The function of these actors is usually to help change the rules of the constitutional state, and/or to bypass them where required.

- Internal-Fixers: technocrats that oversee the subverting or breaking of the rules. Most likely these actors have access to a cache of classified or sensitive information and have inside knowledge of how systems work. Their function is to facilitate "insider trading" and tender fixing.

- External-Fixers: dealers and handlers who launder money, pay bribes, conduct "hits" on opponents (literal or metaphoric) in ways that are coercive and threatening. Legal and auditing professionals are also classified in this group who authoritatively sign off illegitimate and illegal behaviour (e.g., KPMG, Deloitte).

- Brokers: act as coordinators and visionaries of the project. These actors are generally never directly involved in the transactions and activities of corruption. In South Africa, this group would include the Guptas, the Watsons and other politically connected individuals.

- Corrupt Corporates, Middlemen and Influencers: they are involved in the transactions and generally have more formal exchanges (facilitation fees/BEE fronting). Often only take a percentage and then pass on to brokers for distribution (but can also act as brokers). Included in this category are the banks and other financial institutions that facilitate illicit financial flows (money laundering), as well as the private sector companies that derive profits through payments of kickbacks.

\subsubsection{The State of Political Capture}

Though profound significance has been placed on the April 2017 protests, it is important to recognise that in spite of the protests and the substantial pressure from the body politic, it would be a further 10 months before Zuma would be removed 


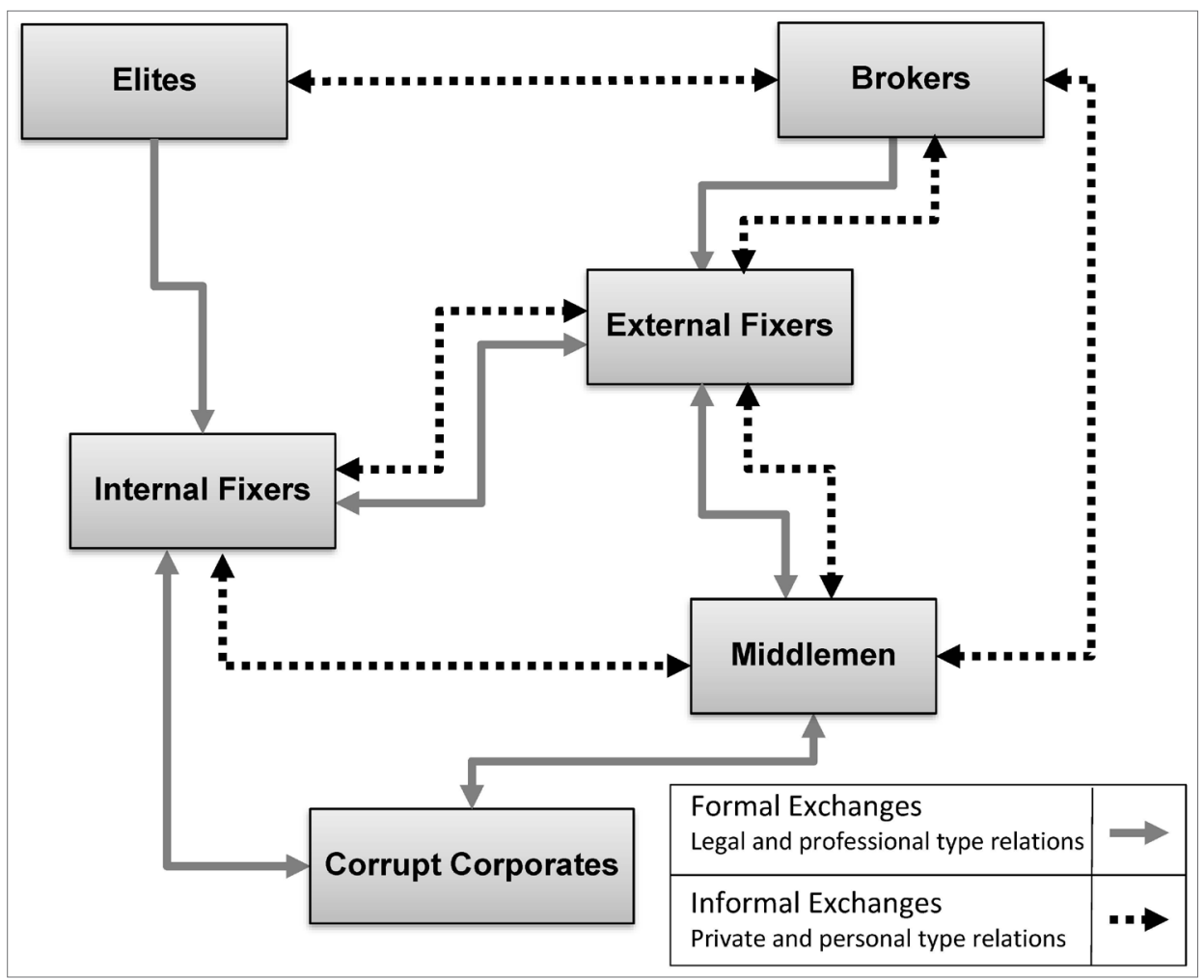

FIGURE 1.2 Relational Dynamics of the Shadow State

from office. It only happened after Cyril Ramaphosa, running on an anti-state capture platform, managed to narrowly beat the 'RET' ('radical economic transformation') faction nominee Nkosazana Dlamini-Zuma at the ANC's national conference in December 2017. The outcomes of the conference are largely viewed as a compromise, where the likes of Ace Magashula (extensively implicated as part of the Gupta network) (Myburgh, 2019) was elected Secretary-General of the ANC and David D. Mabuza was elected Deputy President. Mabuza made a last minute swing of support to Ramaphosa despite having previously anchored the provincial support base for Zuma's faction (Friedman, 2019).

On 14 February 2018, Zuma announced his resignation as President of South Africa in what was arguably one of the most bizarre media briefings. It was unclear at the time if he would step down and from the speech he gave, it was quite apparent he was reluctant to release the reins of power (BizNews, 2018; CNBCAfrica, 2018). For his part, Zuma denies the existence of "state capture" and has been on a campaign to discredit the entire notion. Since the release of the Public Protector's State of Capture (2016) report, he's called it a fake political tool, a "politically decorated expression" 
and has countless times presented himself as a hapless victim under threat. $\mathrm{He}$ acknowledges that something has occurred, but refuses to engage the concept of State Capture: "There are people who did things to others in one form or the other, and you can call it in any other name, not this big name 'state capture"' (Deklerk, 2018; eNCA, 2018).

In quick succession after becoming President of the country, Ramaphosa moved certain compromised ministers out of their various roles in government. Without a clear mandate from the electorate and with such a narrow margin of victory, his Presidency's legitimacy is precarious. The extent to which he could enact bold changes within the party and within the state was limited. For instance, even though he could move Bathabile Dlamini as minister of DSD, he would not remove her from Cabinet entirely (Davis, 2018).

The necessity to make strategic political trade-offs has ensured that certain elements of the shadow state still have access to the political decision-makers and key business brokers. When we take stock of the glaring contradictions and hypocrisy of events and decisions taken, the ANC emerges as a startling reflection of the underlying dynamics of power, money and personality that shape the current political landscape. For instance, on 25 June 2018, the ANC established its manifesto working groups in preparation for the May 2019 national elections. In the document it states emphatically that "We will use Parliament, commissions, investigators and the courts to get to the bottom of the problem and deal with the offenders. As the ANC, we will take strong action against any of our leaders guilty of corruption"(ANC, 2018, p. 51). The irony was that none other than Tony Yengeni, the only individual to have been tried and pled guilty to corruption in the Arms Deal saga (spending a mere 4 months in jail for fraud and corruption), would chair the ANC's anti-corruption committee (Carter, 2006; Mahlati, 2018).

Ramaphosa himself would be caught in controversy when the details of the funding for his political campaign for ANC Presidency were leaked, following an investigation by the current Public Protector. Busisiwe Mkhwebane probed whether or not Ramaphosa lied to parliament about having received a donation from Gavin Watson, the then director of BOSASA (Rabkin, 2019). The findings of the report are being taken on review in the courts and several allegations have been made that Mkhwebane is actively part of what is considered the "fight back" campaign that calls itself the 'Radical Economic Transformation' faction of the ANC that openly campaigns in favour of Jacob Zuma. However, the monetary value attached to the political campaigns and the associated list of funders lays bare the stark reality of the 
embedded power relations that form a bridge between South Africa's corporate and political elites - perhaps the most pervasive racket of them all.

As already argued, the State Capture project is inherently political. This perspective permeates the various chapters as they pertain to the respective case studies. However, it needs to be acknowledged that this book does not present a comprehensive analysis of the political system in its entirety. There is a political dimension to each case of State Capture and as the full extent of State Capture is yet to emerge, so too the extent of political capture - in short, it is a story that is yet to play itself out. As recognised by Deputy Chief Justice Zondo, an understanding of the role of party politics in government, and in parliament particularly and various legislative bodies within the state, still needs to be ascertained.

\subsection{STATE POWER, ACCUMULATION AND THE RACKETS}

An expanding body of literature by a diverse group wanting to explain the absence of fundamental transformation since 1994 has brought into focus the complex dynamics of elite formation (Terreblanche, 2002; Mbeki, 2005; Hart, 2008; Von Holdt, 2019). In essence, the argument is that the black elite that gained access to political power in 1994 lacked any form of significant capital and, therefore, were dependent on state power to create the conditions for accumulation. By contrast, the Afrikaner elite that came to power in the 1940s had significant land and agricultural capital that they leveraged to establish investments in mining, manufacturing and finance. The English-speaking elite that preceded the Afrikaner elite was rooted in mining and (globalised) finance capital. Under these conditions, the black elite was completely dependent on state institutions, with the ANC playing out its new role as key coordinator of what Von Holdt describes as the "informal political-economic system" that evolved during the Mbeki era (Von Holdt, 2019).

The problem with the business class in post-1994 South Africa was not simply that it was largely white, but also its reluctance to be embedded in the South African political economy. Moving capital out of South Africa (using legal and illegal means) has been a top priority for white business elites since 1994, accelerating whenever there is a crisis. "Hence the question", Von Holdt argues, "of a patriotic black bourgeoisie with national commitment, which so exercised Mbeki's mind. These are very political dynamics with a real material content, and place the political economy of a rising class at the centre of ANC politics" (Von Holdt, 2019, p. 6). Despite the emphasis (from 2002 onwards) on the need for a 'developmental state' to manage this (Swilling, 2008), the reliance on BEE, financialisation and shareholder value did not do the trick. The emerging black elite remained relatively small and financially weak. To compensate, 
reliance on state institutions intensified, culminating in the ousting of Mbeki and rise of Zuma to the Presidency with a promise to accelerate the capital accumulation of a new 'black industrial class'. It is worth citing Von Holdt at length:

\begin{abstract}
Numerous black entrepreneurs, and aspirant entrepreneurs, were unable to access these opportunities because of political gatekeeping or because they lacked the capital or the skills. Already, during the Mbeki period as well as the presidency of Mandela, an alternative political-economic system was emerging at national, provincial and local levels, through which networks of state officials, ambitious entrepreneurs as well as smalltime operators, were rigging tenders or engaging in other kinds of fraud so as to use revenue flows from the state to sustain or establish businesses, or simply to finance self-enrichment. Given the property clause in the Constitution, as well as the conservative strategies adopted by the ANC government, and in the context of economic domination by large corporations and white owned businesses, there was little alternative for channelling the aspirations and burning sense of injustice of black elites and would be elites in postapartheid South Africa. The state - newly re-nationalised by the liberation struggle - had become the only channel for the emergence of these aspirant classes, given the scope of its resources and activities. (Von Holdt, 2019, p. 8, emphasis added)
\end{abstract}

As demonstrated elsewhere (Chipkin \& Swilling, 2018), the Zuma government focused on the R200bn per annum procurement spend via SOEs. The argument was that instead of depending on the largesse of white capital, the procurement spend of 'our industries' must be used to foster the development of a 'Black Industrial Class' - the term used in a policy paper published in 2014 by the Department of Trade and Industry. The new Zuma-centred power elite knew that the repurposing of state institutions could not be done by remaining within the parameters of the law and the Constitution. A range of brokers, fixers and middlemen were needed to manage a new generation of transactions. This, in turn, created the material conditions for the emergence of the shadow state. In essence, the 'informal political-economic system' created during the Mbeki era was consolidated, streamlined and centralised via key brokers like the Guptas and Watsons. The end result was the formation of what Olivier de Sardan (2016) calls a "predatory authority" - a mode of governance that is common across many post-colonial African governments with deep roots in racist colonial systems. Political leaders and senior Managers are accorded what Olivier de Sardan calls "royal prerogatives, which their victims describe as rackets". These rackets, he argues,

... appear in the eyes of the beneficiaries, not simply as a matter of personal choice, but rather as a rightful aspect of their office. The latter therefore 'naturally' entails a predatory dimension. A policeman has the right to deduct his dues from transporters, in the same way that a 'directeur de 
cabinet' has the right to dip into special funds, or the customary judge the right to exact fees from offenders. (Olivier de Sardan, 2016, pp. 41-42, emphasis added)

What is missing in the South African literature on State Capture is a narrative that can help to understand the granular micro-dynamics of how these 'rackets' actually get assembled in practice and how they work in everyday life. Yet, in the chapters that follow - and almost every day at the Zondo Commission - there is mounting evidence that there are indeed a definite set of rackets in place that are deployed to enrol thousands of people in a set of relationships that result in the internal moral compromise of individuals and the repurposing of institutions and rent extraction. This is how the 'informal political-economic system' and the shadow state works. It is easy to imagine how all those who 'confessed' to the 'unburdening panel' established by the South African Council of Churches in 2016/2017 expressed what they must have gone through as they got enrolled in these rackets.

The notion of 'rackets' and the 'racket society' evolved out the Frankfurt School of Critical Theory in the 1930s and 1940s to understand the collusion between political and business elites, and is being revived today to comprehend the way corporate and political elites collaborate to achieve shared goals (Jay, 2020). According to Adorno and Horkheimer, "[r]ackets are comprised of and operationalized by cliques, gangs and other established groups that act protectively towards their own members, while externally they attempt to circumvent the market process by misappropriating economic income and by deceiving the public" (Granter, 2017). Most of this kind of literature on rackets is useful because the collaboration between business and political elites is not assumed but described. However, little is revealed about how they work in practice in organisational terms.

For this, we need to turn to the social psychology literature on rackets that refers to "coercive feelings" that are triggered to actively enrol people into a particular set of rackets (Ernst Jr, 1973). These feelings are fear, rage, shame, guilt, desperation, anxiety, helplessness, greed and confusion. These feelings get manipulated in the relationship of power between the racketeer and the person that the racketeer wants to enrol. Each coercive feeling is aimed at engendering a particular response that favours the racketeer. A racket always involves the following mix: an active agent (the 'racketeer'), those who get enrolled in the racket (the 'rackatee', so to speak), a story premised on a fundamental untruth (underlying manipulation) and a 'coercive feeling' or mix of 'coercive feelings' to engineer the relationship and reproduce compliance (Ernst Jr, 1973; Erskine \& Zalcman, 1979; Christoph-Lemke, 1999). A racket, therefore, can be defined as a pattern of behaviour that enables the racketeer to enrol others into acting out a fundamental untruth that is often masked by a seemingly credible story. 
What is recognised in both the 'society of rackets' and psychological racket theory is that rackets are self-perpetuating and re-enforcing (Ernst Jr, 1973; Erskine \& Zalcman, 1979; Christoph-Lemke, 1999; Granter, 2017; Klein \& Regatieri, 2018; Scheit \& Fischer, 2018). These characteristics of rackets helps to bridge the two theories. If an individual racket proves effective, it will most likely continue to be repeated and replicated elsewhere, and thus the racket spreads. Unchallenged, rackets become practised norms within groups. There are numerous examples of these rackets, such as the way that ministers meeting with business people at informal luxury locations gets normalised. Former President Zuma threw a spotlight on this normalised and sanctioned practice when questioned at the Zondo Commission if it was 'okay' for a President to ask a Director General (DG) of a department to "please help" the Gupta's The New Age access advertising budget of the state. He replied, “... if such a call is made, would that call have moved away from the normal procedures, would it be trying to compel the DG to do a wrong thing or whatever, even if the call was made or not made?" (Zondo Commission, 2019a). Ultimately these practised norms become accepted, going on to corrupt social norms. Understanding rackets as an underlying practice (expressed via repeatable patterns of behaviour) helps to perpetuate State Capture by blurring boundaries and normalising the loyalties that exist in informal spaces that subvert the desired norms of accountability (even though these may not have ever existed in practice).

In new democracies, relationship building between elites may be necessary for stability, but it can also oil the wheels of the rackets that reproduce anti-democratic behaviours. The large literature on the developmental state has always wrestled with this tension, but essentially concludes that if this tension resolves in favour of the business elite, then the developmental state is compromised and State Capture follows. The alternative is what Evans famously called "embedded autonomy" - this is when a political elite (that is not totally corrupted) keeps the business elite in check to ensure that national rather than particular interests are promoted (Evans, 1995).

Influenced by the literature on rackets, we have noticed fives kinds of rackets:

- Conspiracy: here two or more relatively autonomous parties mutually agree to cooperate in secret to achieve a shared goal. In this case, the parties enrol reach other in a mutually beneficial racket that operationalises the shared goal. The coercive feeling is often greed. The Transnet South China Rail deal might be a case in point.

- Collusion: this refers to the way a relatively more powerful racketeer uses various 'coercive feelings' to ensure that one or more 'junior' parties agree to actively collude in ways that are often denied by the story that the racketeer tells, and the 
enrolled person chooses to believe. The coercive feeling is fear. A good example is the countless cases where someone is pressurised to grant a contract to a BEE contractor on the grounds that this supports 'black empowerment'.

- Coercion: this refers to the way a racketeer uses various direct and indirect threats to coerce a reluctant party to actively participate in a particular racket. Threats range from getting sacked, to physical violence directed against the individual and/or his/her family, blackmail or exclusion from being considered as a contractor. The coercive feeling is anxiety and desperation. There are countless examples of this, many of whom have given testimony at the Zondo Commission.

- Complicity: this racket is similar to coercion, but the aim is not active enrolment in the racket, but rather passive compliance of someone who knows what is going on but is enrolled to say and do nothing. The coercive feelings are confusion, fear and shame. Perhaps one of the most alarming examples was when in 2011, Rieaz ('Mo') Shaik and other senior officials of the State Security Agency (SSA) decided to halt all investigations into President Zuma's friends the Guptas after it became clear that the President was not pleased to hear they were being investigated (Shaik, 2019). As already noted, complicity is how politicians in parliament and in the governing party were enrolled into the racket.

- Con: this refers to complex rackets where the racketeer sells a story to enrol others on false pretences that the enrolled person fully believes. A good example is Benny Jiyani who agreed to be the BEE partner in VR Laser. Jiyani then facilitated the sale of the remainder of VR Laser shares to Saliem Essa without knowing that the latter was in cahoots with the Guptas. Jiyani believed Essa's story, but after the deal was done the Guptas moved in, forcefully ejected Jiyani from the business and took over (Jiyane, 2019). He was conned. The coercive feelings were confusion, fear and helplessness.

\subsection{UNDERSTANDING THAT STATE CAPTURE IS NOT SYSTEMATIC, BUT SYSTEMIC}

South Africa, like most democratic states, is established on the foundation of a formal legal-rational structure of governance where power is distributed, limited and defined in terms of practical interactive institutions that make, adjudicate and enforce the rule of law. Like all human-centric systems, the successful functioning of this system does not depend on the written word but by the manner in which these laws manifest in the daily lives of people. The enactment of the values and principles from which these laws are conceived require continuous monitoring, reflection and reinforcement (or reform if needed) (Rosenfeld, 2000; Le Roux \& Davis, 2019). 
State Capture is when the formal legal structures are subverted and influenced by the informal structures that have become corrupted and predatory. It is a radical departure from the norms and values upon which a democratic developmental state depends. Like most liberal democracies, the Constitution provides for prerequisite checks and balances that are supposed to limit such abuses of power. However, when those checks become checkboxes and the balancing forces are biased, the system becomes a perpetual reinforcing loop spiralling towards a predatory authoritarian state - a silent coup.

This reinforcing loop of the State Capture project centres around three principal objectives, namely controlling of rents, weakening of accountability and maintaining legitimacy. As discussed above, these three objectives are aligned with the ultimate goal of building and maintaining control of the state to the benefit of a select few. The reinforcing nature of this political project is the reason we define this as the 'Racket of Predatory Power', with the strategy outlined in Figure 1.3 (pp. 28 and 29).

A wide diversity of reputable writers, journalists and academic researchers have contributed chapters to this book. They have a diversity of disciplinary backgrounds and therefore use different methods. Their positionalities also differ, resulting in a rich variety of perspectives. The prevailing methodology is qualitative in nature, with the use of quantitative information where required. Nevertheless, there was a shared research objective, and a core research question. All the contributors came together for a two-day workshop in August 2019. The research objective and research question were discussed here, and refined. Chapter contributors were then required to write up their respective chapters with this research objective and core question in mind. The editors scrutinised and discussed each chapter, providing in most cases extensive feedback until the editors were satisfied that the chapter met the required academic standards and addressed the research question.

The overall research objective was to provide an in-depth understanding of what we called the 'anatomy' of state capture. By 'anatomy' we meant a more extensive multifaceted understanding of state capture that was not limited to one network (e.g., Guptas), nor limited to one period (the 'Zuma era'), nor one sector (the public sector). An 'anatomy' implies an understanding of all the parts, and how they fit together. This was achieved using case studies, historical analysis and conceptual analysis. The research question was as follows: how did particular (usually corrupt) agents manage to repurpose particular institutions to achieve their narrowly defined financial and/or political goals? For this purpose, we introduced the notion of rackets, i.e., practices aimed at enrolling people into activities legitimised by a believable lie. Although few 
of the contributors used this term because we only developed this term after most of the chapters were written, it does get referred to in a number of different ways. The notion of 'rackets' is a particularly novel contribution to the global literature on state capture.

The mounds of evidence produced at the Zondo Commission and the reams collated by the various investigations, court cases and investigative journalism, push us to expand our understanding of State Capture to be way beyond merely a few individuals that did the wrong thing. We may well be seduced by the prospect of implicated figures taking the stand at the Zondo Commission, but what we refer to as State Capture did not start and will not end with Zuma. It existed in a different form under the apartheid regime, evident by the known Sanction Busters and illegal arms sales; the power elites of the Afrikaner Broederbond and the highly corrupted nature of the Bantustans. The chapters presented in Part 1 of this book thus look to unpack the historical roots of State Capture and place our understanding in the broader social, political and economic context.

State Capture aligns state institutions, SOEs and sections of business to reproduce corrupt rent-seeking practices within shadow state systems and flows. A veneer of constitutionalism is maintained to mask the complexities of these neo-patrimonial dynamics. Understanding State Capture as systemic rather than a chain of events helps to reveal how the Presidency became the centre of the spider's web that straddled the constitutional and shadow state, thus enabling the rent-seeking, the hollowing out of accountability and the modes of legitimation.

The next three sections of the book present various cases that reflect the three State Capture motives and dynamics as described above, namely rent-seeking, hollowing out of accountability and modes of legitimation. Part 2 discusses the rent-seeking systems that were established and the various ways in which the modus operandi of State Capture was deployed at some of the biggest SOEs. These cases come closest to the traditional application of the 'State Capture' concept as a form of grand corruption. Part 3 discusses how legitimacy was maintained, albeit in often contradictory ways. The case studies presented under this section outline the ways in which crucial social and democratic institutions did not escape the State Capture project and outline the human cost of the rackets deployed. Part 4 focuses on the systematic capture of the various law enforcement and security institutions that were hollowed out and repurposed, thus reinforcing the weakening of accountability. 


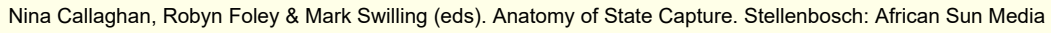 \\ VISUALISING THE RACKET OF PREDATORY POWER}

\section{Manipulate procurement to extract rents}

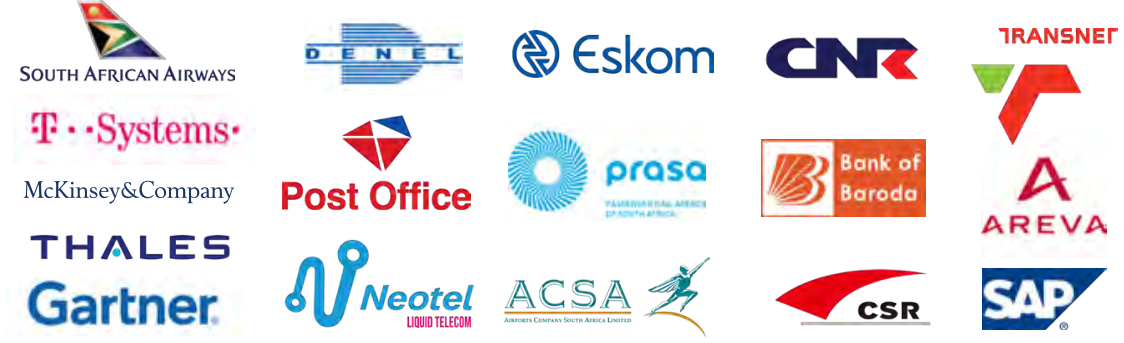

Repurpose law enforcement

HAWKS

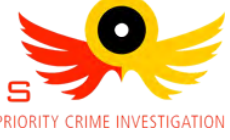

state security

State Security Agency
REPUBLIC OF SOUTH AFRICA
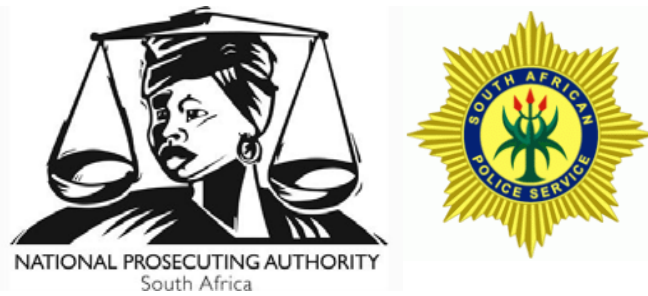

Enable \& protect patronage networks

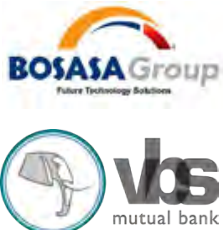

OAM M INVESTMENTS (PTV) LTD.
CWE REGIMENTS

rangewaves

QTRILLIAN

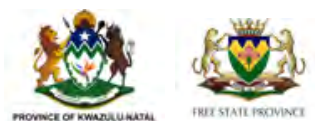

\&霍空

GAUTENG

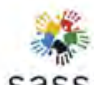

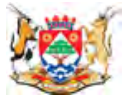

邀

LIMPOPO

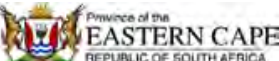




\section{售 \\ What it takes to CAPTURE A STATE}
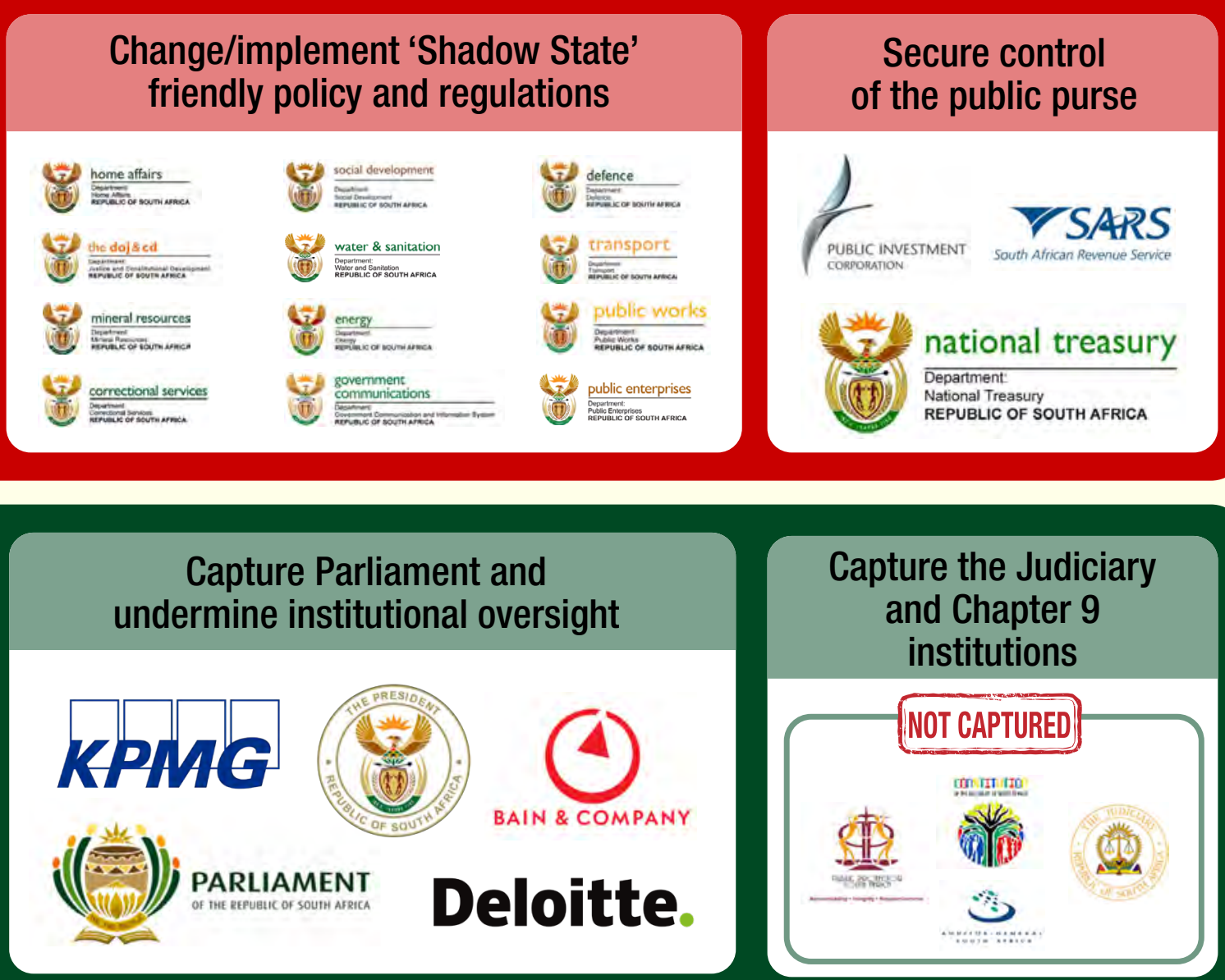

Control the message through the media and drive misinformation

\section{Bell Pottinger}

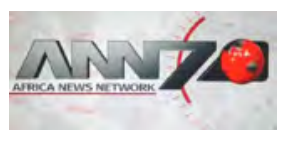

NEWS
Curtail transparency and discredit opposition to the 'Shadow State'

\section{THENEWAGE Sunday Times}

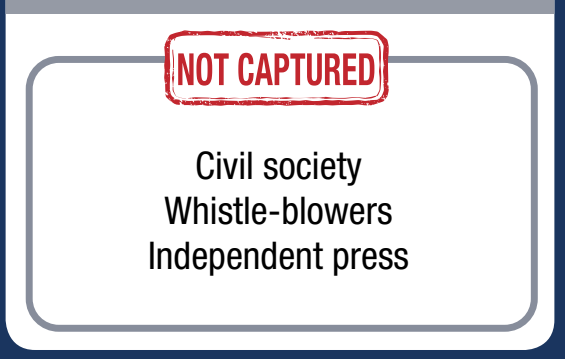


The project of State Capture would also not be possible without the collaboration with those located outside of the state. The familiar modus operandi is clearly evident within and outside the state: the masking of the real interests at play, manipulation of formal processes and normalisation of rackets. Multinational accounting firms like KPMG, Deloitte and McKinsey have all played a role in manipulating the systems of accountability and facilitating the extraction of ill-gotten gains. Investigative outfit, Open Secrets, released a report called The Enablers, which highlights how these private sector elites with global networks like banks, accounting firms, lawyers and consultants facilitated criminal conduct as part of the State Capture project (Open Secrets and Shadow World Investigations, 2020).

When the informal influence of power overrides the formal separations of public good from self-interests, the line separating government and the private sector becomes blurred and vulnerable to corruption. State Capture is also not unique to South Africa and is part of a much bigger breakdown of democracy. The same objectives, strategies and 'modus operandi' exists throughout the world in rising authoritarian states like Kenya, USA, Russia, etc. (Grzymala-Busse, 2008; Yakovlev \& Zhuravskaya, 2009; Ungar, 2016; Meirotti \& Masterson, 2018; Hertel-Fernandez, 2019; Maina, 2019). Part 5 of this book takes the exploration of State Capture into a discussion of the role of the private sector and how the culture of corruption and impunity has proliferated across an array of governance oversight bodies across public and private sectors alike.

It is important to acknowledge that the selection of cases is not definitive, nor do they address all of the dynamics which have been highlighted in this introduction. However, each case does present invaluable insights that reinforce the analysis presented above.

The essence of our argument is that corruption is not in and of itself the key strategic problem. Yes, it is a scourge that must be eliminated. But in reality, it is a symptom of a much larger process of subverting democratic principles of justice, equality and rule of law. Much of current discourse uses the analogy of comparing corruption (and State Capture) to a 'disease' or an illness that can be cured, with a focus on 'removing' or 'ending' or rather 'cutting out the cancer' of corruption.

We argue that this is an incorrect diagnosis as it is based on a few incorrect premises, namely: that corruption is an aberration and that it is not a derivative of an underlying environment/condition. Referring to corruption as a 'cancer that can be cut out' creates the impression that corruption is an isolated phenomenon, something physical and tangible that can be removed from society by an appropriate law enforcement strategy. This diagnosis limits the perspective that is needed to identify the required remedial actions and the structural changes that must be introduced to address the deeper economic challenges of poverty, inequality and the persistence of a class structure 
rooted in South Africa's harsh colonial/apartheid history. Many of the policy responses and most inquiries/commissions have thus been limited to addressing particular instances of corrupt rent-seeking behaviour as one dimension of State Capture. They have failed to address the embedded systemic failures that created the conditions for State Capture and how the various rackets were executed to facilitate State Capture.

State Capture is not just about corruption (though it is key). It is ultimately about the abuse of power and the dismantling of the social compact between society and those who should be considered the 'guardians of governance. The perpetrators of this subversion of the social compact are the politicians, civil servants, directors and executives of companies, auditors, lawyers, financial institutions and journalists that have enabled and executed the political project of State Capture and the broadening out of corrupt practices beyond the state. It is important to note that even though this can be reduced to the decisions and actions of individuals, it is enabled by the underlying rackets that get reproduced within the wider governance ecosystem within and beyond state institutions. It is for this reason that, looking forward, we emphasis the following:

- Government alone cannot address the underlying systemic challenges.

- Removing a few 'sore thumbs' or rotten eggs and tweaking policies and processes will not be sufficient.

- Governance as we know it across the public and private sectors needs to be reformed in ways that explicitly acknowledges the power of rackets and how these have 'normalised' a particular predatory way of doing business in South Africa.

- Mainstream political parties need to re-invent themselves - a new type of leadership is required.

This book is not intended to provide answers or 'solutions' to address State Capture, but rather to provide a foundation for the difficult discussions and complex actions needed to unravel the rackets and address the systemic causes of State Capture. 


\section{References}

Abedian, I. \& Mantell, S. (2017) 'Conjuring fears of systemic risk from KPMG disgrace delays the remedy', Business Day. [Online]. https://bit.ly/37sAfBD (Accessed 27 February 2020).

Abrams, S. (2016) 'Beyond Propaganda: Soviet Active Measures in Putin's Russia, Connections, 15(1):5-31. https://doi.org/ 10.11610/Connections.15.1.01

Ad Hoc Committee on the SABC Board Inquiry (2017) Interim Report of the Ad Hoc Committee on the $S A B C$ Board Inquiry into the Fitness of the $S A B C$ Board, Dated 27 January 2017, Parliament of the Republic of South Africa. Cape Town.

ANC (2018) 'ANC Briefing Notes: Key ANC Policies and Government Programmes a Better Life for All', VoteANC.org. Johannesburg. [Online]. https://bit.ly/ 37sArAR (Accessed 13 January 2020).

Anciano, F. (2018) 'Decolonising Clientelism: "Re-centring" Analyses of Local StateSociety Relations in South Africa, Politikon, 45(1):94-111. https://doi.org/10.1080/025 89346.2018 .1418214

Areff, A. (2015) 'Timeline: How South Africa got three finance ministers in four days', News24. [Online].https://bit.ly/3Ap3cek (Accessed 1 September 2018).

Bach, D.C. (2011) 'Patrimonialism and neopatrimonialism: Comparative trajectories and readings', Commonwealth and Comparative Politics, 49(3):275-295. https://doi.org/10.1080/14662043.20 11.582731

Bhorat, H., Buthelezi, M., Chipkin, I., Duma, S., Mondi, L., Peter., C., Qobo, M., Swilling, M. \& Friedenstein, H. (2017) Betrayal of the Promise: How South Africa is being stolen, State Capacity Research Project. South Africa. [Online]. https://bit.ly/3f Ilyhl

BizNews (2018) 'Word for word: Jacob Zuma's resignation speech, late as ever.' [Online]. https://bit.ly/37zDp6t (Accessed 29 January 2020).

Business Insider SA (2020) 'The biggest South African business scandals over the past decade. [Online]. https://bit.ly/37HXF61

(Accessed 1 March 2020).

BusinessTech (2019) 'How fraud at some of South Africa's biggest companies flew under the radar. [Online]. https://bit.ly/3yKe5qk (Accessed 1 March 2020).

Cameron, J. (2019) 'Eskom attacks Deloitte as fresh corruption scandal erupts: Pay back the money!', BizNews. [Online]. https://bit. ly/3yD0pO0 (Accessed 27 February 2020).

Carter, C. (2006) 'How Yengeni's 4 years in jail became 4 months', IOL News. [Online]. https://bit.ly/3ixRbwS (Accessed 1 March 2020).

Chipkin, I. \& Swilling, M. (2018) Shadow State: The Politics of State Capture. Johannesburg: Wits University Press. https://doi.org/ $10.18772 / 22018062125$

Chirume, J., Hendricks, A., Furlong, A. \& Damba-Hendrik, N. (2017) 'Zuma cabinet reshuffle: what people are saying', Ground Up. [Online]. https://bit.ly/37wDhox (Accessed 1 September 2018).

Christoph-Lemke, C. (1999) 'The Contributions of Transactional Analysis to Integrative Psychotherapy', Transactional Analysis Journal, 29(3):198-214. https://doi.org/ 10.1177/036215379902900305

CNBCAfrica (2018) 'Jacob Zuma resigns as president of South Africa', YouTube. [Online]. https://bit.ly/3iwe8QW (Accessed 29 January 2020).

Constitutional Court of South Africa (2016) 'Economic Freedom Fighters v Speaker of the National Assembly and Others [2016] ZACC 11', Constitutional Court of South Africa.

Constitutional Court of South Africa (2018) 'Corruption Watch NPC and Others v President of the Republic of South Africa and Others [2018] ZACC 23, Constitutional Court of South Africa. [Online]. https://bit. ly/3fJFH7z (Accessed 5 March 2019).

Cowan, K. (2017) 'Inside the great Gupta gathering in Dubai', Business Day. [Online]. https://bit.ly/3lJCVmL (Accessed 29 February 2020). 
Dassah, M.O. (2018) 'Theoretical analysis of state capture and its manifestation as a governance problem in South Africa', The Journal for Transdisciplinary Research in Southern Africa, 14(1):1-10. https://doi.org/10.41 $02 /$ td.v14i1.473

Davis, R. (2018) 'Cabinet Reshuffle: Bathabile Dlamini's appointment disrespects ALL South African women', Daily Maverick. [Online].https://bit.ly/3xxGvT9 (Accessed 1 March 2020).

Davis, R. (2020a) 'Dudu Myeni's unlawful security tactics and dodgy SAA auditing exposed', Daily Maverick. [Online]. https://bit.ly/3lL770W (Accessed 27 February 2020).

Davis, R. (2020b) 'Where to for the Zondo Commission in 2020?', Daily Maverick. [Online].https://bit.ly/31JDoFx (Accessed 23 January 2020).

Deklerk, A. (2018) 'There is no state that was captured - Zuma', Times Live. [Online]. https://bit.ly/3yD1mpy (Accessed 19 November 2019).

Di John, J. (2010) 'The Concept, Causes and Consequences of Failed States: A Critical Review of the Literature and Agenda for Research with Specific Reference to Sub-Saharan Africa, European Journal of Development Research, 22(1):10-30. https://doi.org/10.1057/ejdr.2009.44

eNCA (2018) 'Forner President Jacob Zuma addresses Walter Sisulu students', YouTube. [Online].https://bit.ly/3xrzyDa (Accessed 15 April 2020).

Ernst Jr, F.H. (1973) 'Coercive Feelings: Psychological Rackets in the OK Corral', Transactional Analysis Bulletin, 3(2):19-23. https://doi.org/10.1177/036215 377300300211

Erskine, R.G. \& Zalcman, M.J. (1979) 'The Racket System: A Model for Racket Analysis', Transactional Analysis Bulletin, 9(1):51-59. https://doi.org/10.1177/0362153779 00900112

Eskom (2016) Eskom will continue to insist on procuring coal from 50\%-plus blackowned coal miners. [Online]. https://bit. ly/3fJqgMC (Accessed 31 August 2018).
Evans, P. (1995) Embedded Autonomy: States and Industrial Transformation. Princeton: Princeton University Press. https://doi.org/ 10.1515/9781400821723

Friedman, S. (2019) 'Cabinet picks show Ramaphosa and allies believe they're firmly in control', The Conversation. [Online]. https://bit.ly/3s1tSi4 (Accessed 17 March 2020).

Godinho, C. \& Hermanus, L. (2018) 'Reconceptualising State Capture - With a Case Study of South African Power Company Eskom', State Capture and Its Aftermath: Building Responsiveness Through State Reform. Cape Town: Public Affairs Research Institute.

Gosling, M. (2018) Another victory for environmental duo who put a halt to SA's nuclear deal', Daily Maverick. [Online]. https://bit.ly/3CwNGi7 (Accessed 27 February 2020).

Granter, E. (2017) 'Strictly business: Critical Theory and the society of rackets', Competition and Change, 21(2):94-113. https://doi.org/10.1177/1024529417 690716

Gray, H. \& Whitfield, L. (2014) 'Reframing African Political Economy: Clientelism, Rents and Accumulation as Drivers of Capitalist Transformation', International Development, 14(159):1-33. London. [Online]. https://bit. ly/3s2v04X (Accessed 27 August 2018).

Grzymala-Busse, A. (2008) 'Beyond Clientelism Incumbent State Capture and State Formation', Comparative Political Studies, 41(4/5):638-673. https://doi. org/10.1177/0010414007313118

\#GuptaLeaks (2017a) \#GuptaLeaks: The Dubai Laundromat - How millions from dairy paid for Sun City wedding. [Online]. https://bit. ly/3yBJ34e (Accessed 29 February 2020).

\#GuptaLeaks (2017b) \#GuptaLeaks. [Online]. https://www.gupta-leaks.com/ (Accessed 10 November 2017).

\#GuptaLeaks (2017c) Bell Pottinger - Page 3 Gupta Leaks. [Online]. https://bit.ly/3jyAssx (Accessed 29 February 2020).

Haffajee, F. (2019) 'Ramaphosa's 'nine lost years' speech impresses Old Mutual CEO at Davos', 
Fin24. [Online]. https://bit.ly/3Cwd9bG (Accessed 1 March 2020).

Hart, G. (2008) 'The provocations of Neoliberalism: contesting the nation and liberation after Apartheid', Antipode, 40(4):678-705. https://doi.org/10.1111/ j.1467-8330.2008.00629.x

Hellman, J., Jones, G. \& Kaufmann, D. (2000) 'Seize the State, Seize the Day: An Empirical Analysis of State Capture and Corruption in Transition Economies', World Bank Policy Research Working Paper, Washington, D.C. [Online]. papers2://publication/ uuid/B15B06FA-4346-4788-A9CBC07431F4B63A

Hertel-Fernandez, A. (2019) State Capture: How Conservative Activists, Big Businesses, and Wealthy Donors Reshaped the American States - and the Nation. Oxford University Press.

High-Level Review Panel on the SSA (2018) 'High-Level Review Panel Report on the State Security Agency', South African Government. [Online]. https://bit.ly/3lIAShP

Hofstatter, S. (2018) 'Counting the cost of state capture', Business Day. [Online]. https://bit. ly/31KcOfy (Accessed 16 March 2020).

Hosken, G. (2017) 'The effect of State Capture on the man in the street', Times Live. [Online]. https://bit.ly/3s39U6P (Accessed 16 March 2020).

Jay, M. (2020) 'Trump, Scorsese, and the Frankfurt School's Theory of Racket Society', Los Angeles Review of Books. [Online]. https://bit.ly/3itq1Y6 (Accessed 2 October 2020).

Jiyane, M.J. (2019) 'Statement and Documents Submitted by Madoda John Jiyane', Commission of Inquiry into State Capture. Johannesburg. [Online]. https://bit.ly/ 3ixgPlr

Jonas, M. (2018) 'Statement and Documents Submitted by Mcebisi Jonas', Commission of Inquiry into State Capture. Johannesburg. [Online].https://bit.ly/3CwgwPS

Khan, M.H. (2000) Rents, Rent-Seeking and Economic Development: Theory and Evidence in Asia. Cambridge University
Press. https://doi.org/10.1017/CBO 9781139085052

Klein, S. \& Regatieri, R.P. (2018) 'Unfettered capitalism: On rackets, cronies and mafiosi', Tempo Social, 30(3):67-84. https://doi.org/ 10.11606/0103-2070.ts.2018.146125

Labuschagne, P. (2017) 'Patronage, state capture and oligopolistic monopoly in South Africa: The slide from a weak to a dysfunctional state?', Acta Academica, 49(2):51-67. https:// doi.org/10.18820/24150479/aa49i2.3

Le Roux, M. \& Davis, D. (2019) Lawfare: Judging Politics in South Africa. Johannesburg: Jonathan Ball Publishers.

Lewandowsky, S., Ecker, U.K.H. \& Cook, J. (2017) 'Beyond Misinformation: Understanding and coping with the post-truth era', Journal of Applied Research in Memory and Cognition, 6(4):353-369. https://doi.org/10.1016/j. jarmac.2017.07.008

Mail \& Guardian (2015) 'In pictures: \#ZumaMustFall protests. [Online]. https://bit.ly/3AnIvPF (Accessed 19 November 2019).

Magubane, K. (2019) 'Damage from state capture 'worse than suspected' - SARB', Fin24. [Online]. https://bit.ly/3yBMIWf (Accessed 1 March 2020).

Mahlati, Z. (2018) ANC defends Yengeni appointment as chair of crime and corruption group, IOL News. [Online]. https://bit.ly/ 37qutbN (Accessed 1 March 2020).

Maina, W. (2019) 'State Capture: Inside Kenya’s Inability to Fight Corruption', Africa Centre for Open Governance (AfriCOG). [Online]. https://bit.ly/3fIOSp5

Makhafola, G. (2018) 'State capture results in recession, high unemployment rate commission hears', IOL News. [Online]. https://bit.ly/3yALNyB (Accessed 16 March 2020).

Martini, M. (2014) State Capture: An Overview, Anti-Corruption Helpdesk. [Online]. https:// bit.ly/2VxU8EF (Accessed 23 April 2019).

Mbeki, M. (2005) 'Perpetuating Poverty in Sub-Saharan Africa. How African political elites undermine entrepreneurship and 
economic development', International Policy Network, London.

Meirotti, M. \& Masterson, G. (2018) State Capture In Africa: Old Threats, New Packaging? Johannesburg: EISA. [Online]. https://bit.ly/3xBLFO2 (Accessed 30 January 2019).

Merten, M. (2019) 'State Capture wipes out third of SA's R4.9-trillion GDP - never mind lost trust, confidence, opportunity', Daily Maverick. [Online]. https://bit.ly/2VGjsYZ (Accessed 5 December 2019).

Mitchley, A. (2019) 'Life Esidimeni tragedy: Another NGO ordered to pay back the money', News24. [Online]. https://bit.ly/ 3jAtdjT (Accessed 1 March 2020).

Moerane, M., Gounden, V. \& Potgieter, C. (2018) 'Report of the Moerance Commission of Enquiry into the Underlying Causes of the Murder of Politicians in KwaZulu-Natal', Moerane Commission, Durban. [Online]. https://bit.ly/3jAtjlh (Accessed 17 January 2019).

Moseneke, D. (2018) Life Esidimeni Arbitration Report. [Online]. http://section27.org.za/ (Accessed 23 January 2019).

Myburgh, P.-L. (2019) Gangster State Unravelling Ace Magashule's Web of Capture. Cape Town, South Africa: Penguin Books.

Nene, N. (2018) 'Statement and Documents Submitted by Nhlanhla Nene', Commission of Inquiry into State Capture. [Online]. https://bit.ly/3xy6auQ

O’Donnell, G. (2004) 'Why the Rule of Law Matters', Journal of Democracy, 15:32. https://doi.org/10.1353/jod.2004.0076

Olivier de Sardan, J.P. (2016) 'A Moral Economy of Corruption in Africa?', The Journal of Modern African Studies, 37(1):25-52. https://doi.org/10.1017/ S0022278X99002992

Omarjee, L. (2019) 'Ramaphosa says state capture cost SA more than R500bn, overseas criminals will be brought to book, Fin24. [Online].https://bit.ly/37wGJQ1 (Accessed 1 March 2020).

Open Secrets \& Shadow World Investigations (2020) 'The Enablers: The Bankers,
Accountants and Lawyers that cashed in on State Capture,' Open Secrets. Cape Town.

OUTA (2017) 'The Guptas, the Oberoi and their guests', Organisation Undoing Tax Abuse (OUTA). [Online]. https://bit.ly/3Afv44q (Accessed 29 February 2020).

PARI (2018) 'Evidence for the People's Tribunal on Economic Crime 3. State Capture: The case of Denel and VR Laser', People's Tribunal on Economic Crime. South Africa. [Online]. https://bit.ly/3yBisJK

Pijoos, I. (2017) 'State Capture named SA word of the year', News24. [Online]. https://bit. ly/3xwDGBX (Accessed 3 February 2018).

Pijoos, I. (2018) 'ConCourt ruling on Dlamini, debacle a victory - Black Sash, FUL', News24. [Online]. https://bit.ly/3s45XyM (Accessed 27 February 2020).

President of Republic of South Africa (2018) 'Proclamation NO. 3 of 2018: Schedule Terms of Reference of the Judicial Commission of Inquiry to Inquire into Allegations of State Capture, Corruption and Fraud in the Public Sector including Organs of State', Government Gazette No. 41436. [Online]. https://bit.ly/3scqrFt (Accessed 18 September 2018).

Public Protector (2014) Secure In Comfort. [Online]. https://bit.ly/3yAMA2x (Accessed 1 September 2018).

Public Protector (2016) State of Capture. [Online].https://bit.ly/3lKTnmU (Accessed 1 September 2018).

Rabkin, F. (2019) 'Ramaphosa launches court review of Public Protector's Bosasa Report', Mail \& Guardian. [Online]. https://bit. ly/3fKoU4q (Accessed 1 March 2020).

Richards, D.G. (2008) 'Transition and reform in a predatory state: the case of Paraguay', Journal of Economic Policy Reform, 11(2):101-114. https://doi. org/10.1080/17487870802031403

Rosenfeld, M. (2000) 'The Rule of Law and the Legitimacy of Constitutional Democracy', Southern California Law Review, 74:1307. https://doi.org/10.2139/ssrn.262350

SABC Digital News (2016a) 'Dlamini warns on wrong channels to raise issues within ANC', 
YouTube. [Online]. https://bitly/3scyB0k (Accessed 1 December 2017).

SABC Digital News (2016b) 'Mcebisi Jonas on being offered a job by the Guptas', YouTube. [Online].https://bit.ly/3lYpQ9o (Accessed 1 December 2017).

Scheit, G. \& Fischer, L. (2018) 'Rackets', in B. Best, W. Bonefeld \& C. O'Kane (eds.) The Sage Handbook of Frankfurt School Critical Theory. Sage Publications, pp. 1551-1566. https://doi.org/10.4135/9781526436 122.n94

Shadow World Investigations (2019) First Submission to the Commission of Inquiry Into Allegations of State Capture regarding the Estina/Vrede Integrated Dairy Project. [Online].https://bit.ly/3xBdnKJ (Accessed 29 February 2020).

Shaik, R. (2019) 'Statement and Documents Submitted by Rieaz Shaik', Commission of Inquiry into State Capture.

Snyder, T. (2018) The Road to Unfreedom: Russia, Europe, America. Tim Duggan Books.

Swilling, M. (2008) 'Tracking South Africa's Elusive Developmental State', Administratio Publico. Cape Town: HSRC Press, 16(1):1-29.

Terreblanche, S. (2002) A History of Inequality in South Africa 1652-2002. Scottsville: University of Natal Press.

The Citizen (2017) 'R250bn lost to state capture in the last three years, says Gordhan'. [Online].https://bit.ly/3jQBkca (Accessed 1 March 2020).

Ungar, M. (2016) 'Networks of Criminality: The State and Crime Policy in Contemporary Democracy', Desafios, 28(1):299-231. https://doi.org/10.12804/ desafios28.2.2016.08
Van de Walle, N. (2007) 'The Path from Neopatrimonialism: Democracy and Clientelism in Africa Today', Mario Einaudi Center for International Studies, 3-07. New York: Cornell University. [Online]. https:// bit.ly/3iG1lvv (Accessed 31 August 2018).

Van Zyl, G. 2017. 'Now Fitch downgrades SA to junk - Zuma's wrecking ball in full swing, BizNews. [Online]. https://bit.ly/3CD6i0d (Accessed 29 February 2020).

Von Holdt, K. (2019) 'The political economy of corruption: elite-formation, factions and violence', Society, Work and Politics Institute, Working Paper, Johannesburg, p. 10.

Wicks, B. (2020) 'Breaking: Zondo Commission granted extension', The Citizen. [Online]. https://bit.ly/3IXFXUs (Accessed 27 February 2020).

Wilkinson, K. \& Africa Check (2017) 'Fact Sheet: How many motions of no confidence has Zuma faced?', Eyewitness News. [Online]. https://bit.ly/2VOTrHj (Accessed 18 March 2020).

Yakovlev, E. \& Zhuravskaya, E. (2009) 'State Capture: From Yeltsin to Putin', Corruption, Development and Institutional Design. United Kingdom: Palgrave Macmillan. https:/ / doi.org/10.1057/9780230242173_2

Zondo Commission (2019a) ‘Transcript from Inquiry into State Capture: Day 133 (1507-2019) - Testimony of Jacob Zuma, Commission of Inquiry into State Capture, Johannesburg. [Online]. https://bit.ly/ 3yBycHn

Zondo Commission (2019b) 'Transcript from Inquiry into State Capture: Day 157 (05-09-2019) - Testimonies of Krivani Pillay, Mwaba Phiri and Thandeka Gqubule-Mbeki, Commission of Inquiry into State Capture, Johannesburg. 


\section{APPENDIX}

\begin{tabular}{|c|c|c|c|c|}
\hline $\begin{array}{l}\text { Case Study } \\
\text { in State } \\
\text { Capture }\end{array}$ & Status & Summary Description & $\begin{array}{l}\text { Investigation } \\
\text { Body / } \\
\text { Source of } \\
\text { Evidence }\end{array}$ & $\begin{array}{l}\text { Government } \\
\text { Entity } \\
\text { Implicated }\end{array}$ \\
\hline \multicolumn{5}{|c|}{ Scandals Connected to Jacob Zuma, Guptas, Other Key Networks and ANC Politics } \\
\hline $\begin{array}{l}\text { The State } \\
\text { of Capture } \\
\text { report - } \\
\text { focuses } \\
\text { on Guptas' } \\
\text { relationship } \\
\text { with Jacob } \\
\text { Zuma and } \\
\text { their alleged } \\
\text { influence on } \\
\text { the affairs } \\
\text { of state }\end{array}$ & $\begin{array}{l}\text { First complaint } \\
\text { was received } \\
\text { in March } 2016 \\
\text { and the report } \\
\text { was released in } \\
\text { November } 2016 .\end{array}$ & $\begin{array}{l}\text { Investigation into complaints of alleged improper } \\
\text { and unethical conduct by the President and } \\
\text { other State Functionaries, relating to alleged } \\
\text { improper relationships and involvement of the } \\
\text { Gupta Family in the removal and appointment } \\
\text { of Ministers and Directors of State-Owned } \\
\text { Enterprises (SOEs), resulting in improper and } \\
\text { possibly corrupt award of State Contracts and } \\
\text { Benefits to the Gupta Family's Businesses. } \\
\text { The report details numerous allegations of } \\
\text { the Guptas' involvement in affairs of the state } \\
\text { and their irregular activities that enable rent } \\
\text { extraction. The findings were not conclusive } \\
\text { and the remedial action was to establish a } \\
\text { commission of inquiry into state capture (to } \\
\text { be appointed by the President, but with a } \\
\text { judge selected by the Chief Justice). Litigation } \\
\text { endeavoured to delay or prohibit the report's } \\
\text { release and implementation of remedial actions, } \\
\text { but failed, and the commission was established } \\
\text { in } 2018 \text {. }\end{array}$ & $\begin{array}{l}\text { - Public } \\
\text { Protector, } \\
\text { followed by } \\
\text { litigation }\end{array}$ & $\begin{array}{l}\text { - GCIS (The } \\
\text { New Age) } \\
\text { - Eskom } \\
\text { (Optimum) } \\
\text { - Transnet } \\
\text { (Regiments/ } \\
\text { Trillian) } \\
\text { - Denel } \\
\text { - SAA (The } \\
\text { New Age) } \\
\text { - SABC (The } \\
\text { New Age) } \\
\text { - Department of } \\
\text { Finance } \\
\text { - Transport } \\
\text { (SAA) } \\
\text { - Communica- } \\
\text { tions (SABC } \\
\text { \& GCIS) }\end{array}$ \\
\hline $\begin{array}{l}\text { Zondo } \\
\text { Commission }\end{array}$ & $\begin{array}{l}\text { Established } \\
\text { in 2018, with } \\
\text { anticipated } \\
\text { conclusion being } \\
\text { the end of } 2021 .\end{array}$ & $\begin{array}{l}\text { Formally titled the Judicial Commission of } \\
\text { Inquiry into Allegations of State Capture, } \\
\text { Corruption and Fraud in the Public Sector } \\
\text { including Organs of State, the Commission } \\
\text { was promulgated by then President Zuma in } \\
\text { response to the remedial actions as outlined in } \\
\text { the Public Protector's State of Capture report. } \\
\text { As of June } 2021 \text {, the Commission that started } \\
\text { in August } 2018 \text { has held more than } 418 \text { days } \\
\text { of hearings of over } 330 \text { testimonies (generating } \\
\text { over } 71000 \text { pages of transcript). The inquiry's } \\
\text { terms of reference were expansive and, as } \\
\text { such, the scope of investigations went beyond } \\
\text { merely looking into the Gupta-related cases, } \\
\text { covering other networks (e.g., Bosasa) as well } \\
\text { as other government institutions (e.g., role } \\
\text { of Parliament). }\end{array}$ & $\begin{array}{l}\text { - Zondo } \\
\text { Commission }\end{array}$ & $\begin{array}{l}\text { Various } \\
\text { work-streams } \\
\text { covering } \\
\text { inter alia: } \\
\text { - SOEs } \\
\text { (Eskom, } \\
\text { Transnet, } \\
\text { Denel, SAA) } \\
\text { - Free State } \\
\quad \text { Provincial } \\
\text { Government } \\
\text { - Bosasa } \\
\text { - SARS } \\
\text { - Law } \\
\text { enforcement } \\
\text { - State Security } \\
\text { Agency (SSA) } \\
\text { - The New Age } \\
\text { \& ANN7 } \\
\text { - Role of } \\
\text { Parliament } \\
\text { and ANC }\end{array}$ \\
\hline
\end{tabular}




\begin{tabular}{|c|c|c|c|c|}
\hline $\begin{array}{l}\text { Case Study } \\
\text { in State } \\
\text { Capture }\end{array}$ & Status & Summary Description & $\begin{array}{l}\text { Investigation } \\
\text { Body / } \\
\text { Source of } \\
\text { Evidence }\end{array}$ & $\begin{array}{l}\text { Government } \\
\text { Entity } \\
\text { Implicated }\end{array}$ \\
\hline \multicolumn{5}{|c|}{ Scandals Connected to Jacob Zuma, Guptas, Other Key Networks and ANC Politics } \\
\hline Bosasa & $\begin{array}{l}\text { Dating back to a } \\
2009 \text { SIU report. } \\
\text { Investigations and } \\
\text { various litigations } \\
\text { are ongoing. }\end{array}$ & $\begin{array}{l}\text { In 2019, former Bosasa C00, Anglo Agrizzi, } \\
\text { testified at the Zondo Commission, detailing } \\
\text { the acts and long history of corruption between } \\
\text { various Bosasa companies predominantly } \\
\text { owned by Gavin Watson, and numerous } \\
\text { government entities/departments. The } \\
\text { testimony of Agrizzi (and other former Bosasa } \\
\text { employees) corroborated the findings of a } \\
2009 \text { SIU investigation that alleged corruption } \\
\text { in several contracts Bosasa had with the } \\
\text { Department of Correctional Services. Criminal } \\
\text { court proceedings have been initiated based } \\
\text { on the } 2009 \text { SIU investigation, along with new } \\
\text { investigations initiated by SARS and other law } \\
\text { enforcement entities. }\end{array}$ & $\begin{array}{l}\text { - Special } \\
\text { Investi- } \\
\text { gation } \\
\text { Unit (SIU) } \\
\text { - Zondo } \\
\text { Commission }\end{array}$ & $\begin{array}{l}\text { - Department of } \\
\text { Correctional } \\
\text { Services } \\
\text { - Department of } \\
\text { Justice } \\
\text { - Department of } \\
\text { Home Affairs } \\
\text { - Department of } \\
\text { Transport } \\
\text { - Various SOEs } \\
\text { (e.g., SAPO, } \\
\text { ACSA) } \\
\text { - National } \\
\text { Prosecuting } \\
\text { Authority } \\
\text { (NPA) } \\
\text { - Members of } \\
\text { Parliament }\end{array}$ \\
\hline Arms Deal & $\begin{array}{l}\text { Various } \\
\text { investigations and } \\
\text { sources, dating } \\
\text { back to 1990s. } \\
\text { Most significant } \\
\text { source being } \\
\text { through Seriti } \\
\text { Commission. } \\
\text { Corruption case } \\
\text { against Zuma is } \\
\text { ongoing. }\end{array}$ & $\begin{array}{l}\text { Commission of Inquiry into allegations of fraud, } \\
\text { corruption, impropriety, or irregularity in the } \\
\text { Strategic Defence Procurement Packages } \\
\text { (SDPP). Various court cases related to } \\
\text { allegations of corruption against Jacob Zuma. } \\
\text { On Monday, } 24 \text { October 2011, the President } \\
\text { announced the Commission chaired by Judge } \\
\text { Seriti. The findings of the Commission were that } \\
\text { there was "no evidence" of corruption, but this } \\
\text { is seen by many to have been a whitewash. The } \\
\text { report was taken on review and set aside in } \\
\text { August 2019. The corruption case against Zuma } \\
\text { is ongoing before the courts. }\end{array}$ & $\begin{array}{l}\text { - Seriti } \\
\text { Commission } \\
\text { - Various } \\
\text { court cases }\end{array}$ & $\begin{array}{l}\text { Initially: } \\
\text { - South African } \\
\text { National } \\
\text { Defence } \\
\text { Force } \\
\text { - Members of } \\
\text { Parliament } \\
\text { Allegations also } \\
\text { involve: } \\
\text { - NPA } \\
\text { - SSA }\end{array}$ \\
\hline $\begin{array}{l}\text { Nkandla } \\
\text { Security } \\
\text { Upgrades }\end{array}$ & $\begin{array}{l}\text { Investigation } \\
\text { started in } \\
\text { November } 2012 . \\
\text { Report on } \\
\text { investigation } \\
\text { was released in } \\
\text { March } 2014 .\end{array}$ & $\begin{array}{l}\text { Report on security upgrades to President } \\
\text { Zuma's homestead in Nkandla. The investigation } \\
\text { found that the President unduly benefited from } \\
\text { the upgrades and as part of remedial actions } \\
\text { the President was required to pay back a portion } \\
\text { of the costs of the upgrades. Zuma instructed } \\
\text { that SAPS undertake their own investigation, } \\
\text { which sought to rationalise the expenses (fire- } \\
\text { pool report). Parliament accepted this alternative } \\
\text { report, but major court cases followed, } \\
\text { ultimately declaring that the Public Protector's } \\
\text { remedial actions are binding. President and } \\
\text { Parliament failed to uphold the Constitution. } \\
\text { President ordered to "pay back the money". }\end{array}$ & $\begin{array}{l}\text { - Public } \\
\text { Protector's } \\
\text { Secured } \\
\text { in Comfort } \\
\text { report, } \\
\text { followed by } \\
\text { litigation }\end{array}$ & $\begin{array}{l}\text { - Department of } \\
\text { Public Works } \\
\text { - South African } \\
\text { Police Service }\end{array}$ \\
\hline
\end{tabular}




\begin{tabular}{|c|c|c|c|c|}
\hline $\begin{array}{l}\text { Case Study } \\
\text { in State } \\
\text { Capture }\end{array}$ & Status & Summary Description & $\begin{array}{l}\text { Investigation } \\
\text { Body / } \\
\text { Source of } \\
\text { Evidence }\end{array}$ & $\begin{array}{l}\text { Government } \\
\text { Entity } \\
\text { Implicated }\end{array}$ \\
\hline \multicolumn{5}{|c|}{ Scandals Connected to Jacob Zuma, Guptas, Other Key Networks and ANC Politics } \\
\hline $\begin{array}{l}\text { Private } \\
\text { Aircraft } \\
\text { Landing at } \\
\text { Waterkloof } \\
\text { Airforce Base } \\
\text { and Gupta } \\
\text { Sun City } \\
\text { Wedding }\end{array}$ & May 2013. & $\begin{array}{l}\text { In 2013, justice, crime prevention, and } \\
\text { security cluster (JCPS) - a cabinet structure } \\
\text { composed of various ministries - undertook an } \\
\text { investigation into the Landing of a Commercial } \\
\text { aircraft at Air Force Base Waterkloof (report } \\
\text { titled the same). The investigation revealed that } \\
\text { the Guptas initially tried to organise a special } \\
\text { landing at OR Tambo International Airport, but } \\
\text { was turned down. They then approached the } \\
\text { Indian High Commission who re-designated the } \\
\text { wedding entourage as an official delegation to } \\
\text { secure a landing at the Waterkloof base. The } \\
\text { wedding held at Sun City was attended by a } \\
\text { number of high-profile ANC politicians and was } \\
\text { paid for in part by moneys looted from the Vrede } \\
\text { Dairy Farm project. }\end{array}$ & $\begin{array}{l}\text { - Report by } \\
\text { JPCS } \\
\text { - Zondo } \\
\text { Commission }\end{array}$ & $\begin{array}{l}\text { - Department of } \\
\text { International } \\
\text { Relations and } \\
\text { Cooperation } \\
\text { (DIRCO) } \\
\text { - Department of } \\
\text { Defence } \\
\text { - Department of } \\
\text { Transport }\end{array}$ \\
\hline $\begin{array}{l}\text { Free State } \\
\text { Provincial } \\
\text { Capture, } \\
\text { includes } \\
\text { Vrede Dairy } \\
\text { Farm and } \\
\text { Asbestos } \\
\text { Contracts }\end{array}$ & Ongoing. & $\begin{array}{l}\text { The Vrede Dairy Farm project was initiated } \\
\text { by the Free State Provincial Government as a } \\
\text { development project, however, in partnering with } \\
\text { a Gupta-linked company Estina, government } \\
\text { funds were looted. In 2018, the Public } \\
\text { Protector released a report on their } 2018 \\
\text { investigation, but it was taken on review and } \\
\text { set aside by the courts. The second part of the } \\
\text { investigation is yet to be finalised. The NPA } \\
\text { laid criminal charges against Gupta associates } \\
\text { and implicated government officials. Court } \\
\text { proceedings are ongoing. } \\
\text { Significant testimony and evidence have been } \\
\text { presented at the Zondo Commission regarding } \\
\text { the Vrede Farm case, as well as the asbestos } \\
\text { inspection project (criminal proceedings are also } \\
\text { underway). Both projects implicate high-profile } \\
\text { politicians and senior officials manipulating } \\
\text { government process. }\end{array}$ & $\begin{array}{l}\text { - } \text { Public } \\
\text { Protector } \\
\text { reports } \\
\text { - Zondo } \\
\text { Commission } \\
\text { - Various } \\
\text { court cases }\end{array}$ & $\begin{array}{l}\text { - Free State } \\
\text { Provincial } \\
\text { Government }\end{array}$ \\
\hline $\begin{array}{l}\text { Irregular } \\
\text { removal of } \\
\text { National } \\
\text { Director } \\
\text { of Public } \\
\text { Prosecutions } \\
\text { (NDPP), } \\
\text { Mxolisi } \\
\text { Nxasana }\end{array}$ & $\begin{array}{l}\text { Inquiry instituted } \\
\text { in February } 2015, \\
\text { but was cancelled } \\
\text { in May } 2015 . \\
\text { This triggers the } \\
\text { Constitutional Court } \\
\text { cases that followed. }\end{array}$ & $\begin{array}{l}\text { Inquiry into the fitness of Mxolisi Nxasana to } \\
\text { hold office as NDPP. The Inquiry was cancelled } \\
\text { after Zuma "agreed to let Nxasana resign". He } \\
\text { was paid R17m - the balance of his ten-year } \\
\text { contract. Court cases followed detailing the } \\
\text { abuse of the presidency powers by Zuma. } \\
\text { Ultimately, Nxasana was ordered to repay } \\
\text { R17m and Zuma's appointed replacement, } \\
\text { Shawn Abrahams, was ordered to vacate office. } \\
\text { Constitutional Court found Zuma's actions to } \\
\text { be an abuse of power and in breach of his } \\
\text { constitutional obligations. }\end{array}$ & $\begin{array}{l}\text { - Cassim } \\
\text { Inquiry into } \\
\text { fitness of } \\
\text { Mxolisi } \\
\text { Nxasana to } \\
\text { hold office } \\
\text { of NDPP } \\
\text { initiated } \\
\text { by Zuma, } \\
\text { followed by } \\
\text { litigation }\end{array}$ & $\begin{array}{l}\text { - National } \\
\text { Prosecution } \\
\text { Authority }\end{array}$ \\
\hline $\begin{array}{l}\text { Political } \\
\text { killings in } \\
\text { KZN }\end{array}$ & $\begin{array}{l}\text { Established in } \\
\text { October } 2016 . \text { The } \\
\text { report was released } \\
\text { in May } 2018 .\end{array}$ & $\begin{array}{l}\text { On } 28 \text { October 2016, the Premier of the } \\
\text { Province of KwaZulu-Natal established a } \\
\text { Commission of Enquiry into the Underlying } \\
\text { Causes of the Murder of Politicians in KwaZulu- } \\
\text { Natal (KZN). }\end{array}$ & $\begin{array}{l}\text { - Moerane } \\
\text { Commission } \\
\text { of Enquiry }\end{array}$ & $\begin{array}{l}\text { - KZN Provincial } \\
\text { Government } \\
\text { - KZN Local } \\
\text { Governments }\end{array}$ \\
\hline
\end{tabular}




\begin{tabular}{|c|c|c|c|c|}
\hline $\begin{array}{l}\text { Case Study } \\
\text { in State } \\
\text { Capture }\end{array}$ & Status & Summary Description & $\begin{array}{l}\text { Investigation } \\
\text { Body / } \\
\text { Source of } \\
\text { Evidence } \\
\end{array}$ & $\begin{array}{l}\text { Government } \\
\text { Entity } \\
\text { Implicated }\end{array}$ \\
\hline \multicolumn{5}{|c|}{ Scandals Connected to Jacob Zuma, Guptas, Other Key Networks and ANC Politics } \\
\hline \multicolumn{5}{|c|}{ State Capture of State-Owned Enterprises and Government Departments } \\
\hline $\begin{array}{l}\text { Interference } \\
\text { in operations } \\
\text { at the SABC }\end{array}$ & $\begin{array}{l}\text { The Ad Hoc } \\
\text { Committee was } \\
\text { established in } \\
\text { November } 2016 \\
\text { and final report } \\
\text { was tabled on } \\
24 \text { February } 2017 .\end{array}$ & $\begin{array}{l}\text { Parliamentary Ad Hoc Committee on the } \\
\text { SABC Board Inquiry into mismanagement and } \\
\text { interference in SABC operations. Findings } \\
\text { include evidence of Minister Faith Muthambi's } \\
\text { interference in the organisation and editorial } \\
\text { interference, in the firing of SABC } 8 \text { who } \\
\text { protested censorship of the national broadcaster } \\
\text { (on instruction from COO Hlaudi Motsoeneng). It } \\
\text { should be noted that the inquiry was preceded } \\
\text { by an investigation by the Public Protector. } \\
\text { Details are contained in the } 2014 \text { report titled } \\
\text { When Governance and Ethics Fail. }\end{array}$ & $\begin{array}{l}\text { - Parliamen- } \\
\text { tary Inquiry } \\
\text { - Preceded by } \\
\text { an investi- } \\
\text { gation by } \\
\text { the Public } \\
\text { Protector }\end{array}$ & $\begin{array}{l}\text { - SABC } \\
\text { (Department } \\
\text { of Communi- } \\
\text { cation) }\end{array}$ \\
\hline \multirow[t]{2}{*}{$\begin{array}{l}\text { Passenger } \\
\text { Rail Agency } \\
\text { of South } \\
\text { Africa } \\
\text { (PRASA) }\end{array}$} & $\begin{array}{l}\text { Complaints were } \\
\text { lodged in } 2012 \\
\text { and the report } \\
\text { was released in } \\
\text { August } 2015 .\end{array}$ & $\begin{array}{l}\text { Several cases of "mismanagement and } \\
\text { irregularities" regarding various contracts. } \\
\text { Lucky Montana was CEO at the time. One of } \\
\text { the remedial actions stipulated that National } \\
\text { Treasury was to investigate all PRASA contracts } \\
\text { from } 2012 \text { onwards with a value of R10 million } \\
\text { or more. National Treasury implemented the } \\
\text { remedial action which resulted in several } \\
\text { investigations, the details of which were leaked } \\
\text { to the public. }\end{array}$ & $\begin{array}{l}\text { - Public } \\
\text { Protector's } \\
\text { Derailed } \\
\text { report on } \\
\text { PRASA } \\
\text { - Numerous } \\
\text { investiga- } \\
\text { tions }\end{array}$ & $\begin{array}{l}\text { - PRASA } \\
\text { - Department of } \\
\text { Transport }\end{array}$ \\
\hline & $\begin{array}{l}\text { In June } 2017, \\
\text { Parliament directed } \\
4 \text { committees to } \\
\text { investigate state } \\
\text { capture. Committee } \\
\text { hearings were not } \\
\text { completed. }\end{array}$ & $\begin{array}{l}\text { In terms of the parliamentary directive, the } \\
\text { Portfolio Committee on Transport was requested } \\
\text { to establish an Inquiry into State Capture at } \\
\text { PRASA. However, the Portfolio Committee noted } \\
\text { that PRASA was not mentioned in the Public } \\
\text { Protector's State of Capture report and decided } \\
\text { they would focus on the various investigation } \\
\text { reports produced for National Treasury (as } \\
\text { recommended in Derailed report). }\end{array}$ & $\begin{array}{l}\text { - Portfolio } \\
\text { Committee } \\
\text { on Transport }\end{array}$ & $\begin{array}{l}\text { - PRASA } \\
\text { - Department of } \\
\text { Transport }\end{array}$ \\
\hline $\begin{array}{l}\text { Eskom } \\
\text { Inquiry into } \\
\text { State Capture }\end{array}$ & $\begin{array}{l}\text { In June } 2017 \text {, } \\
\text { Parliament directed } \\
4 \text { committees } \\
\text { to investigate } \\
\text { state capture. } \\
\text { Public Enterprises } \\
\text { Committee } \\
\text { report on Eskom } \\
\text { was released in } \\
\text { November } 2018 .\end{array}$ & $\begin{array}{l}\text { Extensive hearings were held by the Committee } \\
\text { detailing much of the evidence presented in } \\
\text { the Public Protector's report. The Committee } \\
\text { presented recommendations and compiled } \\
\text { a final report detailing their findings. These } \\
\text { included findings that Ministers Lynne Brown } \\
\text { and Malusi Gigaba were negligent and had to } \\
\text { be held accountable. Also recommended that } \\
\text { criminal investigations be undertaken against } \\
\text { the relevant Eskom executives. }\end{array}$ & $\begin{array}{l}\text { - Parliamen- } \\
\text { tary Inquiry }\end{array}$ & $\begin{array}{l}\text { - Eskom } \\
\text { - Department } \\
\text { of Public } \\
\text { Enterprises }\end{array}$ \\
\hline $\begin{array}{l}\text { Nugent } \\
\text { Commission } \\
\text { - SARS } \\
\text { Inquiry }\end{array}$ & $\begin{array}{l}\text { The Inquiry was } \\
\text { constituted on } \\
24 \text { May } 2018 \text { and } \\
\text { the final report } \\
\text { was released in } \\
\text { December } 2018 .\end{array}$ & $\begin{array}{l}\text { Commission of Inquiry into tax administration } \\
\text { and governance by South African Revenue } \\
\text { Service (SARS). Tom Moyane was fired based on } \\
\text { the interim report released in September } 2018 . \\
\text { The inquiry found that Moyane, with the help of } \\
\text { consultancy company Bain, had implemented } \\
\text { restructuring of the organisation, resulting in } \\
\text { gross mismanagement and erosion of SARS. } \\
\text { Moyane motivated the restructuring based on } \\
\text { the "rogue unit" narrative that has been the } \\
\text { subject of several other debunked investigations } \\
\text { and the subject of much litigation. }\end{array}$ & $\begin{array}{l}\text { - Judicial } \\
\text { Commission } \\
\text { of Inquiry } \\
\text { - Court cases } \\
\text { around the } \\
\text { "rogue unit" } \\
\text { narrative }\end{array}$ & $\begin{array}{l}\text { - SARS } \\
\text { (National } \\
\text { Treasury) }\end{array}$ \\
\hline
\end{tabular}




\begin{tabular}{|c|c|c|c|c|}
\hline $\begin{array}{l}\text { Case Study } \\
\text { in State } \\
\text { Capture }\end{array}$ & Status & Summary Description & $\begin{array}{l}\text { Investigation } \\
\text { Body / } \\
\text { Source of } \\
\text { Evidence }\end{array}$ & $\begin{array}{l}\text { Government } \\
\text { Entity } \\
\text { Implicated }\end{array}$ \\
\hline \multicolumn{5}{|c|}{ Scandals Connected to Jacob Zuma, Guptas, Other Key Networks and ANC Politics } \\
\hline \multicolumn{5}{|c|}{ State Capture of State-Owned Enterprises and Government Departments } \\
\hline $\begin{array}{l}\text { Commission } \\
\text { of Inquiry } \\
\text { into Public } \\
\text { Investment } \\
\text { Corporation } \\
\text { (PIC) }\end{array}$ & $\begin{array}{l}\text { In October } 2018 \text {, } \\
\text { the Commission } \\
\text { was constituted, } \\
\text { and the final report } \\
\text { was released in } \\
\text { March } 2020 .\end{array}$ & $\begin{array}{l}\text { Commission of Inquiry into allegations of } \\
\text { impropriety regarding Public Investment } \\
\text { Corporation (PIC). There were extensive hearings } \\
\text { on various 'dodgy' deals the PIC entered } \\
\text { into and details of political and executive } \\
\text { interference in the operations and decision- } \\
\text { making processes of the investment agency. }\end{array}$ & $\begin{array}{l}\text { - Judicial } \\
\text { Commission } \\
\text { of Inquiry }\end{array}$ & $\begin{array}{l}\text { - PIC (National } \\
\text { Treasury) }\end{array}$ \\
\hline $\begin{array}{l}\text { South African } \\
\text { Social } \\
\text { Security } \\
\text { Agency } \\
\text { (SASSA) }\end{array}$ & $\begin{array}{l}\text { Various } \\
\text { Constitutional Court } \\
\text { cases from } 2011 \\
\text { to } 2018 \text { resulted } \\
\text { in removal of CPS } \\
\text { as service provider } \\
\text { to SASSA. }\end{array}$ & $\begin{array}{l}\text { In 2014, South African Social Security Agency's } \\
\text { (SASSA) } 2012 \text { contract with CPS was found } \\
\text { to be irregular and invalid, however, due to the } \\
\text { importance of ensuring beneficiaries received } \\
\text { grants, CPS continued to be the service } \\
\text { providers until } 2018 \text {. Following a March } 2017 \\
\text { ruling, the Constitutional Court instituted a } \\
\text { Section } 38 \text { Inquiry into Minister Bathabile } \\
\text { Dlamini's personal liability for the narrowly } \\
\text { averted grant payment crisis. }\end{array}$ & $\begin{array}{l}\text { Primary } \\
\text { sources: } \\
\text { - AllPay court } \\
\text { case } \\
\text { - Black Sash } \\
\text { court case }\end{array}$ & - SASSA \\
\hline $\begin{array}{l}\text { South African } \\
\text { Airways (SAA) } \\
\text { and SAA } \\
\text { Technical }\end{array}$ & $\begin{array}{l}\text { Court case } \\
\text { to have Dudu } \\
\text { Myeni declared a } \\
\text { delinquent director } \\
\text { was launched } \\
\text { in } 2017 .\end{array}$ & $\begin{array}{l}\text { Court case was launched in } 2017 \text { by Outa and } \\
\text { the SAA Pilots' Association (SAAPA) to declare } \\
\text { Myeni a delinquent director in terms of the } \\
\text { Companies Act, based on her actions while she } \\
\text { was chairperson of the SAA Board. In 2020, the } \\
\text { High Court declared Myeni a delinquent director } \\
\text { for life. A significant amount of new evidence } \\
\text { also emerged through the Zondo Commission, } \\
\text { outlining how the operations at SAA were } \\
\text { undermined and how Myeni and others abused } \\
\text { their positions of authority. }\end{array}$ & $\begin{array}{l}\text { - Court } \\
\text { papers } \\
\text { - Zondo } \\
\text { Commission }\end{array}$ & $\begin{array}{l}\text { - SAA } \\
\text { - SAA Technical }\end{array}$ \\
\hline $\begin{array}{l}\text { Gupta Family } \\
\text { Naturalisation }\end{array}$ & $\begin{array}{l}\text { In June } 2017, \\
\text { Parliament directed } \\
4 \text { committees to } \\
\text { investigate state } \\
\text { capture. Final } \\
\text { report was tabled } \\
14 \text { March } 2019 .\end{array}$ & $\begin{array}{l}\text { Portfolio Committee on Home Affairs Inquiry into } \\
\text { the Gupta Family Naturalisation was established } \\
\text { in terms of the Parliamentary directive. Hearings } \\
\text { formally started on } 12 \text { September 2018. Final } \\
\text { report was tabled on } 14 \text { March 2019. Questions } \\
\text { were raised around contracts with Visa } \\
\text { Facilitation Services. This matter is ongoing as } \\
\text { of December } 2020 \text {. }\end{array}$ & $\begin{array}{l}\text { - Portfolio } \\
\text { Committee } \\
\text { on Home } \\
\text { Affairs }\end{array}$ & $\begin{array}{l}\text { - Department of } \\
\text { Home Affairs }\end{array}$ \\
\hline $\begin{array}{l}\text { Inquiry into } \\
\text { State Capture } \\
\text { related to } \\
\text { Gupta-owned } \\
\text { mines }\end{array}$ & $\begin{array}{l}\text { In June } 2017, \\
\text { Parliament directed } \\
4 \text { committees } \\
\text { to investigate } \\
\text { state capture. }\end{array}$ & $\begin{array}{l}\text { Though the Committee drafted a term of } \\
\text { reference for the Inquiry, the activities of holding } \\
\text { hearings and consolidating the evidence never } \\
\text { materialised beyond questions being put to then } \\
\text { Minister Zwane. }\end{array}$ & $\begin{array}{l}\text { - Portfolio } \\
\text { Committee } \\
\text { on Mineral } \\
\text { Resources }\end{array}$ & $\begin{array}{l}\text { - Department } \\
\text { of Mineral } \\
\text { Resources }\end{array}$ \\
\hline
\end{tabular}




\begin{tabular}{|c|c|c|c|c|}
\hline $\begin{array}{l}\text { Case Study } \\
\text { in State } \\
\text { Capture }\end{array}$ & Status & Summary Description & $\begin{array}{l}\text { Investigation } \\
\text { Body / } \\
\text { Source of } \\
\text { Evidence }\end{array}$ & $\begin{array}{l}\text { Government } \\
\text { Entity } \\
\text { Implicated }\end{array}$ \\
\hline \multicolumn{5}{|c|}{ Scandals Connected to Jacob Zuma, Guptas, Other Key Networks and ANC Politics } \\
\hline \multicolumn{5}{|c|}{ State Capture of State-Owned Enterprises and Government Departments } \\
\hline \multirow{3}{*}{$\begin{array}{l}\text { Various } \\
\text { investigations } \\
\text { relating to } \\
\text { State Capture } \\
\text { at Eskom }\end{array}$} & 2015 & $\begin{array}{l}\text { In 2015, Dentons produced an interim report } \\
\text { on their investigations into Status of Business } \\
\text { and Challenges at Eskom. Their investigation } \\
\text { was halted. }\end{array}$ & - Eskom & - Eskom \\
\hline & \multirow[t]{2}{*}{2017} & $\begin{array}{l}\text { In 2017, PricewaterhouseCoopers (PwC) was } \\
\text { appointed by National Treasury to investigate } \\
\text { Eskom's Coal Procurement Processes. Damning } \\
\text { findings were made in relation to Gupta-owned } \\
\text { Tegeta mine contracts and poor coal quality. }\end{array}$ & - Eskom & - Eskom \\
\hline & & $\begin{array}{l}\text { G9 was contracted by Eskom to investigate } \\
\text { the Trillian/McKinsey contracts. Interim report } \\
\text { presented to Board of Eskom in August } 2017 . \\
\text { The investigation remained incomplete, and } \\
\text { no report is available in the public domain. } \\
\text { Evidence from the investigation was presented } \\
\text { in the Parliamentary Inquiry into Eskom } \\
\text { State Capture. }\end{array}$ & $\begin{array}{l}\text { - National } \\
\text { Treasury }\end{array}$ & - Eskom \\
\hline $\begin{array}{l}\text { National } \\
\text { Treasury } \\
\text { Fundudzi } \\
\text { reports, } \\
\text { related to } \\
\text { Eskom and } \\
\text { Transnet (x3) }\end{array}$ & $\begin{array}{l}\text { Final reports } \\
\text { compiled in } \\
\text { November } 2018 \\
\text { and released to } \\
\text { the public shortly } \\
\text { thereafter. }\end{array}$ & $\begin{array}{l}\text { Investigations requested by National Treasury } \\
\text { of alleged corruption at Transnet and Eskom. } \\
\text { The three reports focused on Eskom (general), } \\
\text { the contracts related to Trillian/McKinsey and } \\
\text { Transnet Locomotives. }\end{array}$ & $\begin{array}{l}\text { - National } \\
\text { Treasury } \\
\text { Fundudzi }\end{array}$ & $\begin{array}{l}\text { - Eskom } \\
\text { - Transnet }\end{array}$ \\
\hline \multirow[t]{2}{*}{$\begin{array}{l}\text { Transnet } \\
\text { Locomotive } \\
\text { Contracts }\end{array}$} & \multirow[t]{2}{*}{$\begin{array}{l}\text { Investigations } \\
\text { commenced in } \\
\text { December } 2017 \\
\text { and reports on } \\
\text { findings submitted } \\
\text { during } 2018 .\end{array}$} & $\begin{array}{l}\text { Werksmans Attorneys was appointed in } \\
\text { December } 2017 \text { to undertake an investigation } \\
\text { into the } 1064 \text { Transnet Locomotives } \\
\text { procurement process, however, the investigation } \\
\text { was halted. No report in the public domain. }\end{array}$ & - Werksmans & - Transnet \\
\hline & & $\begin{array}{l}\text { Mncedisi Ndlovu \& Sedumedi (MNS) Attorneys } \\
\text { was then appointed to investigate } 1064 \\
\text { locomotives procurement process. The report } \\
\text { is not in the public domain, but media indicates } \\
\text { that recommendations mirror the Werksmans' } \\
\text { findings and recommends that Molefe face } \\
\text { criminal charges. }\end{array}$ & $\begin{array}{l}\text { - Mncedisi } \\
\text { Ndlovu \& } \\
\text { Sedumedi }\end{array}$ & - Transnet \\
\hline $\begin{array}{l}\text { Inquiry into } \\
\text { State Capture } \\
\text { at Transnet } \\
\text { and Denel }\end{array}$ & $\begin{array}{l}\text { In June } 2017, \\
\text { Parliament directed } \\
4 \text { committees to } \\
\text { investigate state } \\
\text { capture. Committee } \\
\text { hearings were not } \\
\text { completed. }\end{array}$ & $\begin{array}{l}\text { A detailed information booklet was prepared } \\
\text { in relation to Transnet, however, hearings were } \\
\text { not held before the end of term of Parliament. } \\
\text { Following National elections in 2019, it } \\
\text { was decided that outstanding Inquiries into } \\
\text { state capture be postponed indefinitely until } \\
\text { conclusion of the Zondo Commission. }\end{array}$ & $\begin{array}{l}\text { - Portfolio } \\
\text { Committee } \\
\text { on Public } \\
\text { Enterprises }\end{array}$ & $\begin{array}{l}\text { - Transnet } \\
\text { - Denel }\end{array}$ \\
\hline
\end{tabular}




\begin{tabular}{|c|c|c|c|c|}
\hline $\begin{array}{l}\text { Case Study } \\
\text { in State } \\
\text { Capture }\end{array}$ & Status & Summary Description & $\begin{array}{l}\text { Investigation } \\
\text { Body / } \\
\text { Source of } \\
\text { Evidence }\end{array}$ & $\begin{array}{l}\text { Government } \\
\text { Entity } \\
\text { Implicated }\end{array}$ \\
\hline \multicolumn{5}{|c|}{ Scandals Connected to Jacob Zuma, Guptas, Other Key Networks and ANC Politics } \\
\hline \multicolumn{5}{|c|}{ Law Enforcement and the Security Cluster } \\
\hline $\begin{array}{l}\text { Enquiry into } \\
\text { Jiba and } \\
\text { Mrwebi's } \\
\text { fitness to } \\
\text { hold office } \\
\text { at NPA }\end{array}$ & $\begin{array}{l}\text { Established in } \\
\text { November } 2018 . \\
\text { Report was issued } \\
\text { in April } 2019 .\end{array}$ & $\begin{array}{l}\text { Presidential Enquiry into the fitness to hold } \\
\text { office of suspended NPA senior advocates } \\
\text { Nomgcobo Jiba and Lawrence Mrwebi. NPA's } \\
\text { deputy head Jiba, and Mrwebi, the head of } \\
\text { the Specialised Commercial Crimes Unit, were } \\
\text { suspended in October } 2018 \text { by President Cyril } \\
\text { Ramaphosa. The Inquiry was headed by retired } \\
\text { Constitutional Court Justice Yvonne Mokgoro. } \\
\text { Jiba and Mrwebi were accused of improper } \\
\text { conduct in their handling of cases involving } \\
\text { former crime intelligence head Richard Mdluli, } \\
\text { as well as former KwaZulu-Natal Hawks boss } \\
\text { Johan Booysen. }\end{array}$ & $\begin{array}{c}\text { - Mokgoro } \\
\text { Enquiry }\end{array}$ & $\begin{array}{l}\text { - } \text { National } \\
\text { Prosecuting } \\
\text { Authority }\end{array}$ \\
\hline $\begin{array}{l}\text { High-Level } \\
\text { Review Panel } \\
\text { on the State } \\
\text { Security } \\
\text { Agency (SSA) }\end{array}$ & $\begin{array}{l}\text { Established in June } \\
2018 \text { and final } \\
\text { report was sent to } \\
\text { the President in } \\
\text { December } 2018 .\end{array}$ & $\begin{array}{l}\text { The High-Level Review Panel into the SSA } \\
\text { was established by President Ramaphosa in } \\
\text { June 2018. The key finding was a serious } \\
\text { politicisation and factionalisation of the } \\
\text { intelligence community over the past decade } \\
\text { or more. This resulted in "an almost complete } \\
\text { disregard for the Constitution, policy, legislation } \\
\text { and other prescripts, and [turned] our civilian } \\
\text { intelligence community into a private resource } \\
\text { to serve the political and personal interests of } \\
\text { particular individuals" (High-Level Review Panel } \\
\text { on the SSA, 2018, p.ii). }\end{array}$ & $\begin{array}{l}\text { - Review } \\
\text { Panel } \\
\text { established } \\
\text { by President } \\
\text { Ramaphosa }\end{array}$ & - SSA \\
\hline $\begin{array}{l}\text { Various court } \\
\text { cases against } \\
\text { persons } \\
\text { within law } \\
\text { enforcement }\end{array}$ & Ongoing. & $\begin{array}{l}\text { Though testimony and evidence have been } \\
\text { presented at the Zondo Commission, it is } \\
\text { understood that no definitive findings will be } \\
\text { made regarding the capture of law enforcement } \\
\text { under the Zuma administration. Since } 2012 \\
\text { onwards, there were several court cases } \\
\text { that were pursued against individuals in law } \\
\text { enforcement, all of which have been either } \\
\text { dismissed or withdrawn. Most noteworthy are } \\
\text { the cases involved, amongst others: Anwa } \\
\text { Dramat and Shadrack Sibiya of the Hawks } \\
\text { (and Robert McBride from Independent Police } \\
\text { Investigative Directorate [IPID]) for allegations } \\
\text { related to the "Zimbabwean rendition" matter; } \\
\text { Johan Booysen for alleged racketeering as part } \\
\text { of "Cato Manor hit squad"; and the various } \\
\text { senior officials accused of being part of the } \\
\text { "rogue" intelligence unit at SARS. Other court } \\
\text { cases that have provided significant evidence } \\
\text { indicating the capture of law enforcement relate } \\
\text { to the irregular appointed allies of the Shadow } \\
\text { State capture network or the irrational removal } \\
\text { of potential opponents holding senior positions } \\
\text { in law enforcement. Example is the irregular } \\
\text { removal of Mxolisi Nxasana as National Director } \\
\text { of Public Prosecutions (NDPP). }\end{array}$ & $\begin{array}{l}\text { - Various } \\
\text { court cases, } \\
\text { proceedings } \\
\text { in Parlia- } \\
\text { ment } \\
\text { - Zondo } \\
\text { Commission }\end{array}$ & $\begin{array}{l}\text { - NPA } \\
\text { - SAPS } \\
\text { - Hawks } \\
\text { - IPID }\end{array}$ \\
\hline
\end{tabular}




\begin{tabular}{|c|c|c|c|c|}
\hline $\begin{array}{l}\text { Case Study } \\
\text { in State } \\
\text { Capture }\end{array}$ & Status & Summary Description & $\begin{array}{l}\text { Investigation } \\
\text { Body / } \\
\text { Source of } \\
\text { Evidence }\end{array}$ & $\begin{array}{l}\text { Government } \\
\text { Entity } \\
\text { Implicated }\end{array}$ \\
\hline \multicolumn{5}{|c|}{ Scandals Connected to Jacob Zuma, Guptas, Other Key Networks and ANC Politics } \\
\hline \multicolumn{5}{|c|}{ Investigations concerning Private Sector } \\
\hline $\begin{array}{l}\text { Budlender } \\
\text { report on } \\
\text { Trillian }\end{array}$ & $\begin{array}{l}\text { Released in } \\
\text { June } 2017 .\end{array}$ & $\begin{array}{l}\text { Trillian Holdings Board appointed Geoff } \\
\text { Budlender SC to undertake investigations into } \\
\text { State Capture allegations at Trillian Capital. } \\
\text { Detailed accounts from whistle-blowers } \\
\text { highlighted how information was withheld by } \\
\text { senior management at Trillian. }\end{array}$ & - Trillion & - Eskom \\
\hline $\begin{array}{l}\text { Collapse of } \\
\text { VBS Mutual } \\
\text { Bank }\end{array}$ & $\begin{array}{l}\text { Investigation } \\
\text { launched in } \\
\text { April } 2018 \text { and } \\
\text { the report was } \\
\text { released in } \\
\text { October } 2018 .\end{array}$ & $\begin{array}{l}\text { Minister of Finance placed VBS under } \\
\text { curatorship with effect from } 11 \text { March 2018. In } \\
\text { April 2018, the Deputy Governor of the South } \\
\text { African Reserve Bank instituted an investigation } \\
\text { into VBS. The outcomes of the investigation } \\
\text { showed blatant fraud and corruption by senior } \\
\text { executives/Board and how they extracted } \\
\text { money from the bank. Municipal funds were } \\
\text { illegally deposited with VBS (senior ANC and } \\
\text { EFF politicians have been implicated). }\end{array}$ & $\begin{array}{l}\text { - SARB } \\
\text { investiga- } \\
\text { tion report } \\
\text { VBS Mutual } \\
\text { Bank - The } \\
\text { Great Bank } \\
\text { Heist }\end{array}$ & $\begin{array}{l}\text { - Several } \\
\text { Provincial and } \\
\text { Municipal } \\
\text { Officials } \\
\text { (Limpopo } \\
\text { Government) } \\
\text { - SOEs } \\
\text { (particularly } \\
\text { PRASA) }\end{array}$ \\
\hline $\begin{array}{l}\text { SA Institute } \\
\text { of Chartered } \\
\text { Accountants' } \\
\text { (SAICA) } \\
\text { investigation } \\
\text { into KPMG }\end{array}$ & $\begin{array}{l}\text { Final report was } \\
\text { handed to SAICA in } \\
\text { December } 2018 .\end{array}$ & $\begin{array}{l}\text { SA Institute of Chartered Accountants (SAICA) } \\
\text { established an Inquiry to investigate state } \\
\text { capture related allegations of misconduct of its } \\
\text { members who worked for KPMG. The Inquiry } \\
\text { chaired by advocate Dumisa Ntsebeza held } \\
\text { public hearings and handed its final report to } \\
\text { SAICA in December 2018. Indications are that } \\
\text { the final report will not be made public until all } \\
\text { investigations and disciplinary hearings have } \\
\text { been finalised. }\end{array}$ & - SAICA & - Guptas \\
\hline Bell Pottinger & $\begin{array}{l}2017 \text { investigation } \\
\text { by PRCA. }\end{array}$ & $\begin{array}{l}\text { In 2016, the Guptas appointed British PR } \\
\text { company, Bell Pottinger, who developed and } \\
\text { promoted a campaign that underpinned the RET } \\
\text { and WMC narratives. In 2017, there was an } \\
\text { independent law firm review by Herbert Smith } \\
\text { Freehills resulting in Bell Pottinger's expulsion } \\
\text { from the Public Relations and Communications } \\
\text { Association (PRCA). }\end{array}$ & $\begin{array}{l}\text { - PRCA } \\
\text { - GuptaLeaks } \\
\text { - Ongoing } \\
\text { research } \\
\text { on disinfor- } \\
\text { mation }\end{array}$ & - Guptas \\
\hline
\end{tabular}

